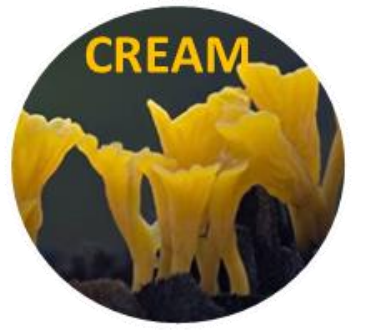

\title{
Diversity of agaric mycota of Western Ghats of Karnataka, India
}

\author{
Senthilarasu $\mathbf{G}^{1}$ and Kumaresan $\mathbf{V}^{2}$ \\ ${ }^{1}$ SRM Research Institute, SRM University, Kattankulathur 603203, Tamil Nadu, India \\ ${ }^{2}$ Department of Plant Science, Bharathidasan Govt. College for Women, Puducherry 605003, India.
}

Senthilarasu G, Kumaresan V 2016 - Diversity of agaric mycota of Western Ghats of Karnataka, India. Current Research in Environmental \& Applied Mycology 6(1), 75-101, Doi $10.5943 / \mathrm{cream} / 6 / 2 / 3$

\begin{abstract}
The morpho-taxonomy of 15 agaric species belonging to Agaricales collected from dipterocarp forests of Western Ghats of Karnataka is briefly described, discussed and their geographic distribution in India is presented. Of these, Crepidotus payettensis is reported for the first time from India. Cyptotrama asprata, Hygrocybe acutoconica, H. alwisii, Oudemansiella furfuracea, Hypholoma subviride and Lactocollybia epia are reported for the first time from Karnataka State. The taxonomy of Oudemansiella furfuracea and Hypholoma subviride contravening to the current name in Index Fungorum is discussed. In addition, a checklist of agarics comprising of 121 species in 55 genera reported from Western Ghats of Karnataka is also provided on the basis of published sources. Overall, 132 species in 60 genera belonging to Agaricales, Polyporales and Russulales are presented in this paper.
\end{abstract}

Key words - Basidiomycetes - bibliography - dipterocarp forests - mushroom taxonomy- tropical fungi

\section{Introduction}

The Western Ghats is recognized as one of the world's eight 'hottest hotspots' of high level of biological diversity and endemism (Myers et al. 2000). It falls in a tropical climate and represents non-equatorial tropical evergreen forests, and harbors unique fungal diversity in addition to globally threatened flora and fauna. Several species of agarics recorded as well as new species described from Kerala (Faroork et al. 2013), Maharashtra (Senthilarasu 2014), and Tamil Nadu (Natarajan et al. 2005a) have not been recorded else where so far. In Karnataka State, about 38,284.3 $\mathrm{km}^{2}$ forest area constitutes $20 \%$ its geographical area. Although the dense forests of Western Ghats that covers about $60 \%$ of the forest area of Karnataka harbors huge number of fungal species, much of the geographic area has not yet been mycologically explored particularly for agaric fungi. Swapna et al. (2008), Pushpa \& Purushothama (2011, 2012), Karun \& Sridhar (2013, 2014, 2015), Karun et al. (2014), Ghate et al. (2014), Ghate \& Sridhar (2015) and Greeshma et al. (2015) fragmentaly reported the agaric mycota of Karnataka State, yet the extent of its diversity in Western Ghats of Karnataka remains poorly known. Agarics in the neighbouring states of Kerala and Maharashtra have recently been compiled and published by Farook et al. (2013) and Senthilarasu (2014), respectively. In this paper, the agaric species encountered from dipterocarp forests of Kodagu and Shimoga districts of Western Ghats of Karnataka are reported. In addition, due to need of a compiled data on the number 
of species confined to Western Ghats as well as Karnataka, a check list of agaric species so far reported from this region is presented based on validly published sources.

\section{Materials \& Methods}

Collection trips were made to dense wet evergreen dipterocarp forests of Kadamakal Reserve Forest in Kodagu district and dipterocarp forests of Sirsi of Uttara Kannada district during monsoon and post monsoon seasons. Kadamakal Reserve Forest near Manaduka, Kothanaduka and Uppangala is in the foothills of the Ghats and lies at $12^{\circ} 30^{\prime} \mathrm{N}, 75^{\circ} 39^{\prime} \mathrm{E}$ at an altitude comprised between 400 and $600 \mathrm{~m}$ asl. Annual rainfall is about 5,200 mm with a marked dry season of 3-4 months. The natural vegetation belongs to the Dipterocarpus indicus Bedd. - Kingiodendron pinnatum (DC.) Harms Humboldtia brunonis Wall. type of low elevation moist evergreen forests (Pascal 1988). Although several hundred plant species have been observed in the forest itself, it is less rich and diverse than other tropical rain forests in South East Asia or South America. Half of the species present in the Kadamakal Reserve Forest are endemic to the Western Ghats and about $80 \%$ of the trees belong to these endemic species (Pascal \& Pélissier 1996). Sirsi located at Uttara Kannada district lies at $14.62^{\circ} \mathrm{N}, 74.85^{\circ} \mathrm{E}$ at an average elevation of $590 \mathrm{~m}$ asl. The forests near Sirsi are moist deciduous forests dominated by Vateria indica $\mathrm{L}$.

The morphotaxonomic characters were adopted from Largent (1977) and Singer (1986). Color terms and notations in parentheses are those of Kornerup \& Wanscher (1978). All measurements and colors reported for microscopic features were observed from dried material rehydrated in $10 \% \mathrm{KOH}$, stained in $2 \%$ phloxine, cotton blue, cresyl blue and Melzer's reagent. The measurements excluding the apiculus and ornamentation were made on 50 basidiospores. The mean spore measurements are given in parentheses followed by the range of spore measurements with extreme values in parentheses. The spore quotient $(\mathrm{Q})$ was obtained by mean length divided by mean width ratio of a spore in profile view. All exsiccata were deposited at Herbarium of Madras University Botany Laboratory (MUBL) and also in personal collections (Macrofungal Collection of India, MCI).

The checklist on gilled mushrooms reported from Western Ghats of Karnataka is prepared based on validly published reports and the agarics reported from other regions of Karnataka are excluded from the list. Index Fungorum (www.indexfungorum.org) and Species Fungorum (www.speciesfungorum.org) websites are generally followed for the nomenclature and currently accepted name, respectively. However, the disputed genera and species are discussed and names accepted by modern authors are adopted for a couple of species. The names of the species and author citations as reported in the cited publications are replaced by currently accepted names with author citations. The checklist is organized alphabetically by order, family, genus and species. The most uncommon species enlisted without description in the validly published reports are excluded from the list. Several corrections are made where orthographic variants found in the cited publications.

\section{Taxonomy}

Anthracophyllum nigritum (Lév.) Kalchbr. Grevillea 9: 137 (1881)

Fig. 1a

Pileus 2-10 $\mathrm{mm}$ diam., reniform to dimidiate; surface uniformly tomato red (8C8), becoming dark on drying, dry, smooth; margin regular, smooth, incurved, radially faintly striate. Lamellae adnate, radiating from the point of attachment, violet brown (10F4), drying black, narrow, subdistant with lamellulae of three lengths. Stipe rudimentary, substipitate, lateral, $1 \times 1 \mathrm{~mm}$, concolorous with the pileus. Context very thin, pale brown, consisting of tightly interwoven, thin-walled, hyaline hyphae, containing numerous, black incrusting particles, becoming dark green in alkali solution. Basidiospores $(5 \pm 0.5 \times 3 \pm 0.2),(4) 4.5-6(6.5) \times(2) 2.5-3.5 \mu \mathrm{m}, \mathrm{Q}=1.6$, oblong, hyaline, inamyloid, thin-walled, smooth, with few refractive guttules. All hyphae bearing clamp-connections.

Specimens examined - India, Karnataka State, Kodagu district, Uppangala Forest, on fallen twigs, scattered, gregarious, 23 June 2001, coll. Senthil. (Herb. MUBL 3436), 11 August 2010, (MCI 1349). 


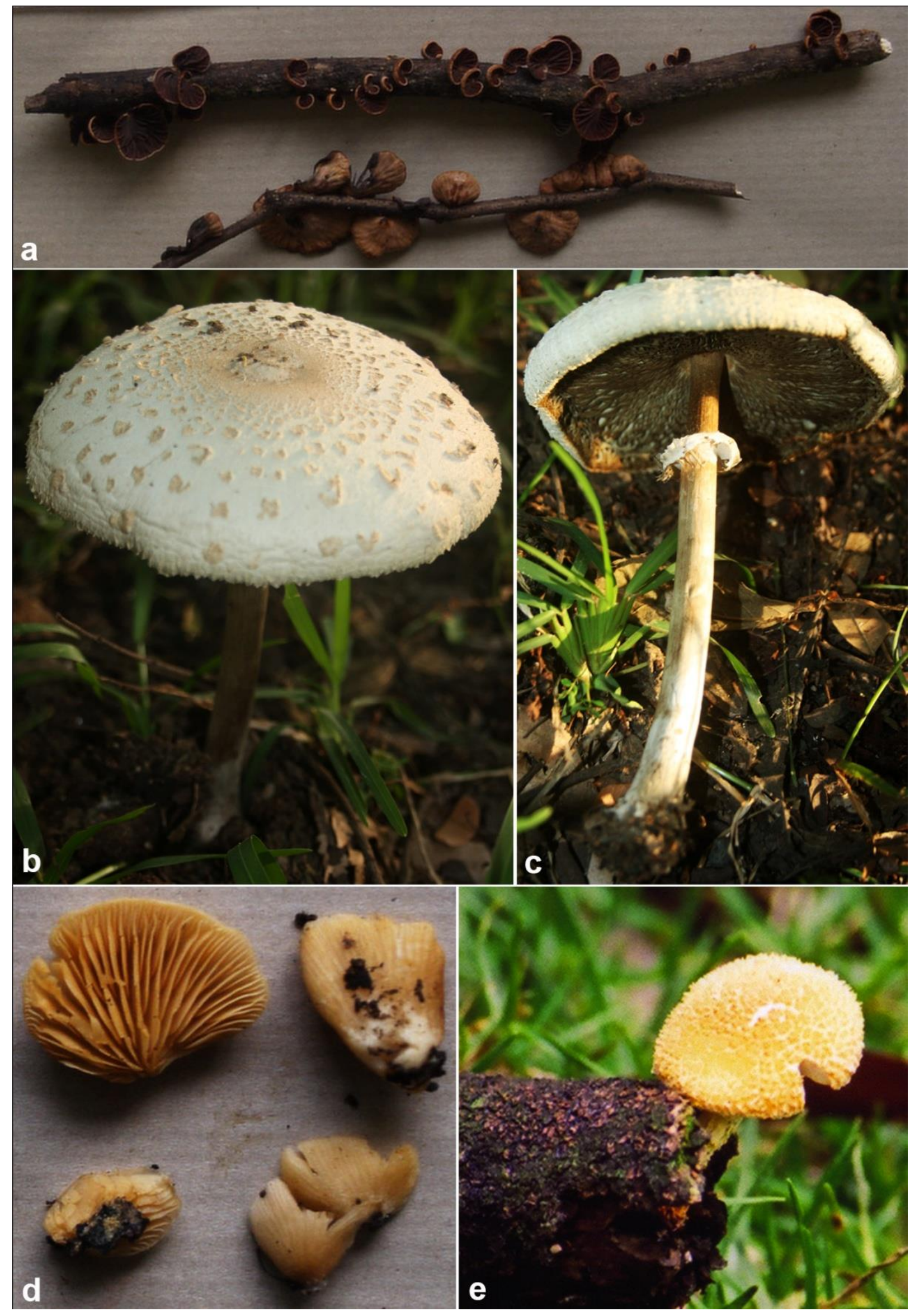

Fig. 1 - a, Anthracophyllum nigritum on dead twigs. b-c, Chlorophyllum molybdites basidiomes under natural conditions. b, Surface view. c, Gill view. d, Crepidotus payettensis. e, Cyptotrama asprata on a dead twig. 
Notes - The genus Anthracophyllum Ces. erected by Cesati (1879) from Sri Lankan material collected by Beccari in the Peradenia Royal Botanic Gardens is characterized by unique hymenophores possessing brownish to red pigments and carbonaceous granules that become bluish green in alkali solution. Several species assigned to Anthrocophyllum were earlier described in Xerotus Fr. (Segedin 1994). The species are confined to pantropical, subtropical, and Australasian localities. In India, A. nigritum and A. lateritium (Berk. \& M.A. Curtis) Singer have been reported. Anthracophyllum nigritum is a common xerophytic and paleotropical species found on dead twigs in damp areas, easily distinguished by small, dimidiate to reniform basidiomes having violet brown to black hymenophore containing carbonaceous granules that become green in alkali solution, and highly branched, diverticulate hyphae in the cuticular layer, with all hyphae bearing numerous clampconnections. Another common species A. lateritium (Putzke 2002) macroscopically resembles A. nigritum in similar sized and shaped basidiomes, but differs microscopically in having larger basidiospores $(9.5-12.5 \times 5.5-8.0$ vs 4-6.5 × 2-3.5 $\mu \mathrm{m})$. Sathe \& Kulkarni (1980) earlier reported $A$. nigritum from Castle Rock, Uttara Kannada of Karnataka.

Known distribution - ASSAM, Khasi Hills (Berkeley 1854 as Xerotus lobatus Berk.; Bresadola 1920); KARNATAKA, Uttara Kannada, Castle Rock (Sathe \& Kulkarni 1980); TAMIL NADU, Nilgiri Hills (Montagne 1856 as Xerotus perrottetii Mont.); Kodaikanal, Tiger Shola (Manjula 1983); MAHARASHTRA, Khandala (Bhide et al. 1987); Mahabaleshwar; Mulshi (Senthilarasu 2014).

Coprinellus disseminatus (Pers.) J.E. Lange [as 'disseminata'], Dansk bot. Ark. 9 (no. 6): 93 (1938)

Pileus 3-10 mm diam., at first ovoid, then conic to campanulate, membranous; surface uniformly violet grey (17C2), often light yellow (4A4) at the disc, glabrous, smooth; margin regular, sulcate striate almost to the disc. Lamellae adnexed, moderately crowded, narrow, $\leq 2 \mathrm{~mm}$ broad, whitish soon becoming 'henna' dark brown (7E8), non-deliquescent, with lamellulae of different lengths. Stipe 12-30 $x \leq 1 \mathrm{~mm}$, slender, cylindric, equal, hollow; surface white, glabrous, almost translucent, arising from white, mycelial threads. Context thin. Basidiospores $(7.3 \pm 0.7 \times 4 \pm 0.2)$, $(5.5) 7-8(9) \times 3.5-4.5 \mu \mathrm{m}, \mathrm{Q}=1.8$, ellipsoid, broadly ovate in face view with a thick, complex wall, truncated by an apical germ-pore, dark brown, deeply pigmented, pigment easily removed by conc. $\mathrm{H}_{2} \mathrm{SO}_{4}$, smooth. Clamp-connections absent.

Specimens examined - India, Karnataka State, Kodagu district, Uppangala Forest, on stump, caespitose to connate, 24 June 2001, coll. Senthil. (Herb. MUBL 3475).

Notes - The coprinoid species earlier treated in the genus Coprinus s. 1. (Redhead et al. 2001) is polyphyletic. Based on new amendments on morphological characters and molecular studies several coprinoid species have been segregated from Coprinus s. 1. and assigned to three new genera Coprinellus P. Karst., Coprinopsis P. Karst. and Parasola Redhead, Vilgalys \& Hopple of the family Psathyrellaceae Vilgalys, Moncalvo \& Redhead (Redhead et al. 2001). The morphological features adopted to delimit the genera are the colour of the immature lamellae, type of pileipellis, presence or absence of pileocystidia, veil tissue, central stipe strand, pleurocystidia and ozonium, di-, tri- or tetramorphous basidia, and nature of deliquescence (Redhead et al. 2001, Moncalvo et al. 2002). Consequently, all the coprinoid species that were earlier assigned in Coprinaceae Overeem \& Weese were distributed in two families Agaricaceae Chevall. (Coprinus Pers.) and Psathyrellaceae (Coprinellus, Coprinopsis and Parasola).

The genus Coprinellus is defined by deliquescent or non-deliquescent basidiomes having white immature lamellae, hymeniderm or cystoderm pileipellis with pileocystidia, granular veil tissue, di-, tri- or tetramorphic basidia, and absence of central stipe strand. The pleurocystidia and ozonium may or may not present. Coprinellus disseminatus is a non-deliquescent, tiny, fragile, coprinoid mushroom growing gregariously on rotting stumps, and buried, decaying woods and roots. The characteristic features of $C$. disseminatus are the convex, gray pileus with light yellow disc, presence of dark brown and deeply pigmented, ellipsoid to broadly ovate spores with an apical truncate germ pore. Swapna et al. (2008) earlier reported this species as Coprinus disseminatus (Pers.) Gray from Shimoga of Western Ghats of Karnataka.

Known distribution - This species has earlier been reported as Coprinus disseminatus from different regions of India. KARnATAKA, Shimoga (Swapna et al. 2008); Bangalore (Pushpa \& 
Purushothama 2012); KerAla, Nilambur, Chandhkkunnu; Thrissur, Peechi (Mohanan 2011 as Coprinus disseminatus var. disseminatus (Pers.) Gray); MAHARASHTRA, Pune (Sathe \& Rahalkar 1975, Sathe \& Deshpande 1982); PUNJAB, Bir Bhadson and Samana (Atri \& Kaur 2002); SIKKIM, Barsey Rhododendron Sanctuary (Das 2009); UtTaR PRAdesh, Lucknow (Ghosh et al. 1967); JAMMU \& KASHMIR, Dachigam National Park (Watling \& Gregory 1980); WEST BENGAL, Calcutta (Banerjee 1947 as Psathyrella); Darjeeling (Roy \& Samajpati 1978, Rai et al. 2005); Sundarbans mangrove forest (Dutta et al. 2013); lateritic region of West Bengal (Pradhan et al. 2013).

Chlorophyllum molybdites (G. Mey.) Massee, Bull. Misc. Inf., Kew: 136 (1898)

Fig. 1b, c

Pileus 90-170 mm diam., fleshy, plane with a shallow umbo; surface rust brown (6E8) at the disc, pale orange (5A3) elsewhere, brownish grey (5D2) at extreme margin; margin sulcate striate for a short distance, becoming eroded. Lamellae free, remote from the stipe, pale yellow (3A3), becoming green, $\leq 20 \mathrm{~mm}$ broad, moderately crowded, with lamellulae of five different lengths. Stipe 90-140 × 10-13 mm, cylindric, expanding below, $\leq 30 \mathrm{~mm}$ diam.; surface whitish, then oak brown (5D6), silky and glabrous. Annulus superior, attached to the upper third of the stipe, later mobile, thick, fleshy, double. Context of pileus $\leq 12 \mathrm{~mm}$ thick at the disc, floccose, pale pinkish, cinnamon. Basidiospores (10.9 $\pm 0.8 \times 7.4 \pm 0.5),(6) 9-11.5(12.5) \times(4.5) 6-8(8.5) \mu \mathrm{m}, \mathrm{Q}=1.5$, ellipsoid, apically truncated by a broad germ pore, wall smooth, apparently 3 layered, greenish in $\mathrm{KOH}$, dextrinoid, usually containing a single, large, verdigris green guttule. Clamp-connections present.

Specimens examined - India, Karnataka State, Kodagu district, Uppangala Forest, on soil, solitary, scattered, 25 June 2001, coll. Senthil. (Herb. MUBL 3470), Manaduka Forest, 11 August 2010, (MCI 1394).

Notes - Species of Chlorophyllum Massee form large, fleshy, basidiomes that are easily recognized in the field and quite often misidentified with another fleshy species of Macrolepiota s.str. Chlorophyllum differs macroscopically in having smooth stipe and microscopically having hymenidermal pileipellis and basidiospores without or with a germ pore caused by a depression in the episporium rather than coloured, banded, squamulose stipe, trichodermal pileipellis and a germ pore caused by a hyaline covering as in Macrolepiota s.str. Based on molecular phylogeny several species that were previously described in Macrolepiota Singer, M. abruptibulba (R. Heim) Heinem., M. alborubescens (Hongo) Hongo, M. bohemica (Wichanský) Krieglst. \& Pázmány, M. globosa Mossebo, M. neomastoidea (Hongo) Hongo, M. olivieri (Barla) Wasser and M. rachodes (Vittad.) Singer were transferred to Chlorophyllum (Vellinga 2002). Chlorophyllum molybdites a tropical and subtropical species has been widely reported from different regions of India. The distinguishing characters of $C$. molybdites are the larger basidiomes having scaly pileus, free, whitish lamellae, becoming greenish with age, movable, thick annulus, elongated, thick, smooth stipe and larger, three layered, greenish, dextrinoid spores with a broad germ pore. Chlorophyllum rachodes (Vittad.) Vellinga a closely related species differs from $C$. molybdites in having whitish to brownish lamellae, not becoming green with age and a thick stipe with abruptly bulbous base. Chlorophyllum molybdites is being reported for the first time from Western Ghats of Karnataka.

Known distribution - KARnATAKA, Bangalore (Pushpa \& Purushothama 2012); Mangalore, Konaje village (Greeshma et al. 2015); KERALA, Ernakulam; Thrissur; Idukki; Thiruvananthapuram (Sankaran \& Florence 1995, Florence \& Yesodharan 1997, 2000, Bhavanidevi 1998, Mohanan 2003, Florence 2004, Pradeep \& Vrinda 2007, Mohanan 2011, Vrinda \& Pradeep 2011); MAHARASHTRA, Pune (Sathe \& Rahalkar 1976, Sathe \& Deshpande 1980, Sathe \& Deshpande 1982); Kolhapur (Patil \& Thite 1978); Amravathi (Hedawoo 2010); TAMIL NADU, Chennai, Madras University Campus (Natarajan \& Manjula 1981); Uttar Pradesh, Lucknow (Ghosh et al. 1976); Allahabad (Singh \& Mehrotra 1974).

\section{Crepidotus payettensis Hesler \& A.H. Smith., North American species of Crepidotus: 88 (1965)}

Fig. 1d

Pileus 10-25 mm diam., dimidiate to flabelliform, thin; surface light orange (5A4) near attachment, brownish orange (6C8) elsewhere, moist, smooth, glabrous; margin regular, entire, translucent striate to sulcate striate. Lamellae adnate, apricot yellow (5B6), $\leq 5 \mathrm{~mm}$ broad, moderately 
spaced with lamellulae of three lengths; edge concolorous, entire. Stipe absent. Attachment lateral, basal mycelium present. Context white, thin, neither duplex nor gelatinized. Basidiospores $(6.8 \pm 0.5 \times$ 5.5 \pm 0.4$),(5.5) 6-7.5(8.5) \times(3.5) 4.5-6(6.5) \mu \mathrm{m}, \mathrm{Q}=1.23$, subovoid to broadly ellipsoid, with a brown, thickened wall, bearing distinct echinulae, with single large, refractive guttule. Clampconnections present.

Specimens examined - India, Karnataka State, Kodagu district, Uppangala Forest, on twigs, scattered, gregarious, 20 June 2002, coll. Senthil. (Herb MUBL 3488).

Notes - The diagnostic features of $C$. payettensis are the dimidiate, sessile basidiomes having brownish orange, smooth pileus lacking fibrillose hairs, subovoid to ellipsoid basidiospores and presence of clamp-connections. Crepidotus payettensis is a North American species described by Hesler \& Smith (1965). The present collection can be placed in the section Fulvidi Hesler \& Smith (lacking pleurocystidia) of the subgenus Dochmiopus (Pat.) Pilát (having ellipsoid spores and presence of clamp connections) of Crepidotus and the phenotypic characters agree with the description of $C$. payettensis (Hesler \& Smith 1965). Although this is a temperate species, this has also been reported from Guangdong Province of China (Bi et al. 1993). Crepidotus kauffmanii Hesler \& A.H. Sm. (Hesler \& Smith 1965) closely resembles $C$. payettensis in all the characters but differs in basidiomes having light buff to fawn to tawny olive pileus, bearing dense avellaneous to wood brown to vinaceous cinnamon fibrils and presence of brown, incrusted epicuticular hyphae, whereas, C. payettensis has smooth pileus with repent cuticular layer consisting of thin-walled, hyaline hyphae. Crepidotus payettensis is being reported for the first time from India.

Known distribution - Karnataka State, Kodagu district, Uppangala Forest

Cyptotrama asprata (Berk.) Redhead \& Ginns, Can. J. Bot. 58(6): 731 (1980)

Fig. 1e

Pileus $\leq 16 \mathrm{~mm}$ diam., convex, shallowly, narrowly depressed at the center; surface uniformly golden yellow (4A5), covered by concolorous, crowded, furfuraceous to granular squamules. Lamellae adnate, white, crowded, $\leq 2 \mathrm{~mm}$ broad, with lamellulae of three different lengths. Stipe $20 \times$ $2 \mathrm{~mm}$, equal, cylindric; surface concolorous with the pileus to pale yellow (5A4), covered by concolorous, superficial squamules. Veil fugacious, white. Context thin, white. Basidiospores $(7.9 \pm 0.7 \times 4.8 \pm 0.8),(7) 8-9(9.5) \times(4) 4.5-5(6) \mu \mathrm{m}, \mathrm{Q}=1.6$, oblong-limoniform with an attenuate apex, hyaline, thin-walled, containing a single, large refractive guttule.

Specimens examined - India, Karnataka State, Kodagu district, Uppangala Forest, on twigs, solitary, 27 June 2001, coll. Senthil. (Herb. MUBL 3450).

Notes - Cyptotrama asprata is a pantropical, saprophytic species growing on twigs or wood and widely distributed in tropical regions. The diagnostic features of the present collection are the convex, uniformly golden yellow pileus and stipe, covered by dark orange, furfuraceous to granular squamules, presence of oblong-limoniform spores with an attenuate apex. Further, the pileal surface is a disrupted trichodermial palisade formed by branching chains of cylindric-clavate to globose elements with thick, golden brown wall. The spore size is very variable in $C$. asprata (Redhead \& Ginns 1980). The dimension of the basidiospores of the present collection falls well within the range $(7.5-10 \times 5-7.5 \mu \mathrm{m})$ reported by Pegler (1977) as Xerulina asprata (Berk.) Pegler. Cyptotrama asprata is being reported for the first time from Karnataka.

Known distribution - KerAla, Idukki, Pampadumshola, Malapuram, Chandhakkunnu, Wayanad, Kuruva (Mohanan 2011); TAMIL NADU, Kodaikanal (Manjula 1983).

Cystoagaricus trisulphuratus (Berk.) Singer, Mycologia 39(1): 87 (1947)

Fig. $2 b$

Pileus 10-30 mm diam., convex; surface reddish orange (7A8), covered by thick, small, flocculose, imbricate, appressed squamules, concolorous with the pileus; margin at first involute, strongly appendiculate, with velar remnants. Lamellae free, pale pinkish, becoming dark vinaceous brown (8D4), $\leq 5 \mathrm{~mm}$ broad, crowded. Stipe 10-55 $\times 1-3 \mathrm{~mm}$, equal, cylindric, fistulose; surface concolorous with the pileus below the annulus, light orange (5A4) above, covered by the pulverulent veil. Annulus superior, attached to the upper quarter of the stipe, floccose, fugacious. Context $1-2$ $\mathrm{mm}$ thick at the disc. Basidiospores $(5.3 \pm 0.5 \times 3.7 \pm 0.2),(4) 5-6(7) \times(3) 3.5-4(4.5) \mu \mathrm{m}, \mathrm{Q}=1.4$, ellipsoid, adaxially applanate, fairly thick-walled, bistre brown. 
Specimens examined - India, Karnataka State, Kodagu district, Manaduka Forest, soil, solitary, scattered 23 June 2001, coll. Senthil. (Herb. MUBL No. 3474), Sirsi, 10 October 2012, (MCI 1372).

Notes - Cystoagaricus trisulphuratus (Psathyrellaceae Vilgalys, Moncalvo \& Redhead) earlier reported as Agaricus trisulphuratus Berk. in Agaricaceae Chevall. can easily be distinguished in the field itself by small basidiomes having reddish orange pileus and stipe with well developed, concolorous, detersile universal veil on both the pileal and stipe surfaces and indistinct, floccose annulus at the apex of the stipe. Cystoagaricus trisulphuratus differs from its morphologically closest taxon Agaricus crocopeplus Berk. \& Broome (Agaricaceae) in the absence of distinct annulus, brown spores with slightly irregular outline and presence of clamp connections.

Known distribution - KARNATAKA, Bangalore (Pushpa \& Purushothama 2012 as Agaricus trisulphuratus Berk.); Mangalore (Ghate et al. 2014); Konaje Village (Greeshma et al. 2015 as Agaricus crocopeplus); KerAlA, Malappuram; Thiruvananthapuram; Alapuzha; Palakkad; Kollam (Pradeep \& Vrinda 2007 as Agaricus trisulphuratus); Wayanad, Thirunelly; Nilambur, Chandhakkunnu (Mohanan 2011); MaharashTrA, Pune (Sathe \& Deshpande 1982); Mulshi (Senthilarasu 2014); Ratnagiri (Borkar et al. 2015 as Agaricus trisulphuratus); PunJAB, Patiala, Punjabi University (Saini et al. 1991, Atri et al. 2001), Fatehgarh Sahib, Aam Khas Bagh (Atri et al. 2001); TAMIL NADU, Chennai (Natarajan \& Manjula 1981); Villupuram, Pichandikulam Forest; Oorani Forest (Mani \& Kumaresan 2009); UtTaR Pradesh, Dehra Dun (Bakshi 1974); WeSt BENGal Calcutta (Bakshi 1974 as Agaricus trisulphuratus); (Pradhan et al. 2013 as Agaricus trisulphuratus).

Hygrocybe acutoconica (Clem.) Singer, Lilloa 22: 153 (1951) [1949]

Fig. 2a

Pileus $15-70 \mathrm{~mm}$ diam., conical, becoming convex, then expanding to plane, but retaining an acute umbo; surface high red (9A8) at the center, reddish orange (7A8) elsewhere when young, Persian orange (6A7) to deep orange (6A8) in the center, yolk yellow (4B8) elsewhere at maturity, smooth, silky fibrillose, striate at the margin; margin splitting irregularly with age. Lamellae adnexed, at first butter yellow (4A5), then yellowish white (3A2), $\leq 12 \mathrm{~mm}$ broad, subdistant. Stipe 40-80 $\times 4$ $7 \mathrm{~mm}$, slender, cylindric to compressed; surface uniformly melon yellow (5A6) to chrome yellow (3A8), becoming whitish towards the base at maturity, smooth. Basidiospores $(8.5 \pm 0.7 \times 4.6 \pm 0.4)$, (7)7.5-9.5(10.5) $\times 4-5(6) \mu \mathrm{m}, \mathrm{Q}=1.84$, broadly ellipsoid, hyaline, inamyloid, thin-walled, often containing numerous, minute, refractive guttules.

Specimens examined - India, Karnataka State, Kodagu district, Manaduka Forest, on ground, solitary to scattered, gregarious, 2 June 2002, coll. Senthil. (Herb. MUBL 3425).

Notes - Hygrocybe acutoconica is a very distinctive species by its small to medium sized, non blackening basidiome having red to deep orange, acute pileus, yellow to yellowish white, adnexed lamellae and yellow to orange yellow stipe with white base. The fresh specimens of Hygrocybe cuspidata (Peck) Murrill differs from $H$. acutoconica in having blood red, viscid pileus. However, when faded, species of $H$. cuspidata are not distinguishable from $H$. acutoconica even in herbarium specimens unless the red colour is retained by the pileus (Hesler \& Smith 1963). The spore dimensions of Karnataka collections fall within the range of Kerala collections (Leelavathy et al. 2006) but smaller $(9-15 \times 5-9$ vs 7-10.5 $\times 4-6 \mu \mathrm{m})$ than the collections described as Hygrophorus acutoconicus var. acutoconicus (Clem.) A.H. Sm. by Hesler \& Smith (1963). Hygrocybe acutoconica is being reported for the first time from Western Ghats of Karnataka.

Known distribution - KeRALA, Thiruvananthapuram (Vrinda et al. 1995 as H. konradii R. Haller Aar.); Malappuram, Calicut University Campus (Leelavathy et al. 2006 as H. acutoconica var. acutoconica (Clem.) Singer); Wayanad, Chandhanathodu (Mohanan 2011 as H. acutoconica var. acutoconica).

Hygrocybe alwisii (Berk. \& Broome) Pegler, Kew Bull., Addit. Ser. 12: 66 (1986)

Fig. $2 d$

Pileus 20-65 mm diam., conic, becoming convex, retaining umbo; surface uniformly yellowish white (2A2), smooth. Lamellae adnexed, whitish. Stipe 50-70 × 3-7 mm, cylindric, white, smooth. Basidiospores dimorphous: macrospores (7.3 $\pm 0.5 \times 6.5 \pm 0.2),(6) 7-8(9) \times(5) 5.5-6.5(8), \mu \mathrm{m}, \mathrm{Q}=$ 1.12, subglobose to broadly ellipsoid, hyaline, thin-walled with single, large refractive guttule; 
microspores $(5.5 \pm 0.5 \times 4.2 \pm 0.3), 4-6(6.5) \times 3-4(4.5) \mu \mathrm{m}, \mathrm{Q}=1.3$, ellipsoid to broadly ellipsoid, similar to macrospores.

Specimens examined - India, Karnataka State, Kodagu district, Manaduka Forest, on ground, solitary to scattered, 22 June 2001, coll. Senthil. (Herb. MUBL 3426), 11 August 2010, (MCI 1374).

Notes - The small to medium sized, shiny, white basidiomes of $H$. alwisii are easily recognized in the field. Hygrocybe alwisii macroscopically resembles H. incolor Pegler (Pegler 1976) in almost similar sized and coloured basidiome, but differs microscopically in having dimorphous spores and basidia. Hygrocybe alwisii is being reported for the first time from Karnataka State. The species reported without taxonomic description as H. alwisii by Ghate \& Sridhar (2015) from mangrove forests of Mangalore, Karnataka appears to be a different species.

Distribution - KerAlA, Thiruvananthapuram; Malappuram; Wayanad; Palakkad; Kollam (Vrinda et al. 1996, Leelavathy et al. 2006, Pradeep \& Vrinda 2007, Mohanan 2011); Maharashtra, Pune, Pune University Campus; Mulshi (Senthilarasu 2014).

Hygrocybe astatogala (R. Heim) Heinem., Bull. Jard. Bot. État Brux. 33(2): 436 (1963) ～Fig. 2c Pileus $45 \mathrm{~mm}$ diam., acutely conical, with pointed umbo, $\leq 40 \mathrm{~mm}$ high; surface uniformly deep red (10C8) to brownish red (10D8), yellowish white (4A2) at extreme margin, covered by appressed, blackish fibrils, shiny, viscid when wet, pellucid striate; margin crisped, becoming eroded, blackening. Lamellae free to adnexed, pale yellow (3A3), becoming black, crowded with lamellulae of different lengths, finely eroded. Stipe $100 \times 7 \mathrm{~mm}$, cylindrical, slightly tapering towards apex; surface whitish to yellowish white $(2 \mathrm{~A} 2,3 \mathrm{~A} 2)$ below, grayish yellow $(2 \mathrm{~B} 3,2 \mathrm{~B} 4)$ to dull yellow (3B3) above, smooth, becoming black on bruising or on injury. Pileus context $\leq 4.5 \mathrm{~mm}$ thick near stipe, yellowish, becoming black. Basidiospores $(9.3 \pm 0.4 \times 6.4 \pm 0.1),(7) 8-10(10.5) \times(5.5) 6-7 \mu \mathrm{m}, \mathrm{Q}$ $=1.46$, ellipsoid to broadly ellipsoid, hyaline, thin-walled with numerous guttules.

Specimens examined - India, Karnataka State, Uttara Kannada district, Sirsi, dipterocarp forest, on soil, solitary, 10 October 2012, coll. Senthil. (MCI 1375).

Notes - Hygrocybe astatogala is a bright coloured species that can easily be identified in the field by small to medium sized basidiomes having conic to conico-convex, bright red to reddish brown, shiny pileus, yellow lamellae, yellow to yellowish orange stipe, pileus and stipe covered by blackish fibrils and all the tissues becoming black on bruising. Hygrocybe astatogala has usually subglobose spores. However, the shape of the spore is dependent on type of the substratum (Monks 1989, Young \& Mills 2002). The present collection has ellipsoid to broadly ellipsoid spores similar to H. astatogala reported from Kerala (Leelavathy et al. 2006) and Maharashtra (Senthilarasu 2014). Hygrocybe conica (Schaeff.) P. Kumm. the closest nigrescent species macroscopically differs in lacking blackish fibrils on pileus and stipe and $H$. acutoconica differs in non blackening basidiomes lacking blackish fibrils.

Known distribution - KARNATAKA, Mangalore, Konaje Village (Greeshma et al. 2015); KeralA, Malappuram, Calicut University Campus (Leelavathy et al. 2006); Wayanad, Begur, Kuruva; Trissur, Peechi (Mohanan 2011); MAHARASHTRA, Mahabaleshwar, Lingamala Falls (Senthilarasu 2014); Sindhudurg; Raigad; Thane; Ratnagiri (Borkar et al. 2015 as Hygrocybe conica).

Hypholoma subviride (Berk. \& M.A. Curtis) Dennis, Kew Bull. 15(1): 134 (1961)

Fig. $2 \mathrm{e}$

Pileus 5-25 mm diam., convex, expanding to plane, broadly umbonate; surface uniformly spring green (30C7) when young, grayish orange (5B4) at the disc, spring green (30C7) elsewhere at maturity, smooth, dry, glabrous; margin regular, decurved, not-striate. Lamellae adnate, moderately close, spring green (30C7) to pale yellow (4A3), becoming yellowish brown, narrow, $\leq 2 \mathrm{~mm}$ broad, with few lamellulae of two lengths. Stipe 5-15 $\times 1-2 \mathrm{~mm}$, equal, cylindric, hollow; surface concolorous with the lamellae, slender, smooth. Context thin, pale. Basidiospores $(5.7 \pm 0.5 \times$ 3.4 \pm 0.3$),(4.5) 5-6(7.5) \times(2.5) 3.5-4(4.5) \mu \mathrm{m}, \mathrm{Q}=1.6$, elongate to ellipsoid, yellowish brown, smooth, apically truncated by a broad germ-pore, with a thick complex wall, with one to few refractive guttules. 

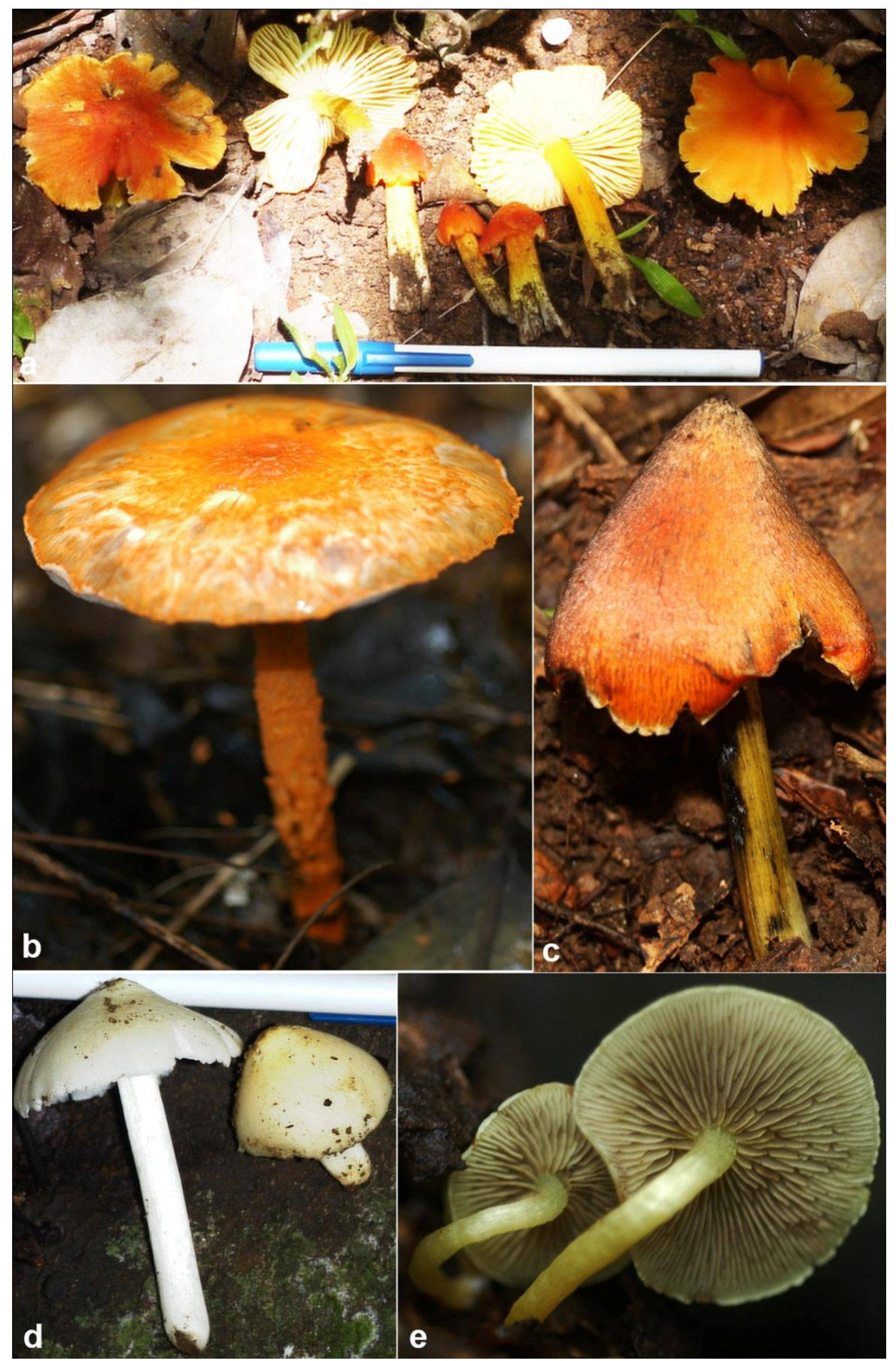

Fig. 2 - Basidiomes in their natural habitat. a, Hygrocybe acutoconica. b, Cystoagaricus trisulphuratus. c, Hygrocybe astatogala. d, Hygrocybe alwisii. e, Hypholoma subviride. 
Specimens examined - India, Karnataka State, Kodagu district, Uppangala Forest, tree trunk, dead wood, completely decayed wood, caespitose to connate, 22 June 2001, coll. Senthil. (Herb. MUBL No. 3477), 11 August 2010 (MCI 1382).

Notes - The species of Hypholoma (Fr.) P. Kumm. (Strophariaceae Singer \& A.H. Smith) earlier placed in Naematoloma P. Karst. are small to medium sized mushrooms distributed from temperate to tropical regions, growing gregariously on dead wood logs, stumps, decayed woods, tree trunks, and soil near logs, among Sphagnum mosses, swamps, and marshes (Singer 1986). The valid name of $H$. subviride is in dispute. Current name of $H$. subviride is $H$. fasciculare (Huds.) P. Kumm. (www.indexfungorum.org). However, examination of several collections from Brazil by Cortez \& Silveira (2007) revealed, H. fasciculare morphologically clearly distinguished from $H$. subviride in having larger pileus (10-70 mm, Cortez \& Silveira 2007; 20-80 mm, Bessette et al. 1997) and stipe (30-100 × 4-10 mm Cortez \& Silveira 2007; 50-120 mm × 3-10 mm, Bessette et al. 1997), little developed veil on pileal surface and having a blackish, faint annular zone at the stipe apex. Further, the phylogenetic analysis by Moncalvo et al. (2002) and Ramírez-Cruz et al. (2013) resulted that these two species are distinct but closely related. Hence the name $H$. subviride is retained here.

The characteristic features of this collection are the smaller, brightly coloured basidiomes having spring green pileus with grayish orange disc, spring green to yellowish lamellae with concolorous stipe, and spores with truncate germ pore. This species is being reported for the first time from Western Ghats of Karnataka.

Known distribution - KerALA, Ernakulam, Perumbavoor, Iringole Kavu (Mohanan 2011); TAMIL NADU, Nilgiris, Lovedale; Naduvattum (Natarajan \& Raman 1983 as Naematoloma subviride (Berk. \& M.A. Curtis) A.H. Sm.).

Lactocollybia epia (Berk. \& Broome) Pegler, Kew Bull., Addit. Ser. 12: 77 (1986)

Fig. 3a

Pileus 10-20 mm diam., convex, expanding to plane; surface uniformly white, smooth, glabrous; margin entire, translucent striate. Lamellae adnate, white, crowded with numerous lamellulae. Stipe 10-25 × 1-2 mm, central to eccentric; surface white, smooth. Context thin, white. Basidiospores $(7.0 \pm 0.4 \times 3.7 \pm 0.2),(6) 6.5-7.5(8) \times(3) 3.5-4.5 \mu \mathrm{m}, \mathrm{Q}=1.89$, elongate, broadly amygdaliform, hyaline, thin-walled, smooth, inamyloid, containing a few refractive guttules.

Specimens examined - India, Karnataka State, Kodagu district, Uppangala Forest, scattered on tree trunk and twigs, 27 June 2002, coll. Senthil. (Herb. MUBL 3432), Manaduka, 11 August 2010, (MCI 1380).

Notes - Lactocollybia Singer is a common tropical genus and the species are mostly distributed in southern hemisphere, extended to North America and grows gregariously or scattered on living tree trunks, barks and at the base of the stumps. The diagnostic features of L. epia are the small, uniformly whitish basidiomes having amygdaliform spores and abundant gloeocystidia on the sides of the lamellae and presence of extensive gloeosystem in the pileal context and gill trama. The spore dimensions of the Karnataka collections are almost similar to L. microspora Singer $(5.5-7 \times 3-5 \mu \mathrm{m}$, Cortez \& Sulzbacher 2009) and L. aequatoriales Singer $(6-9 \times 2.5-4.5 \mu \mathrm{m}$, Cortez \& Sulzbacher 2009) and smaller than the collections of L. epia from East Africa $(7.5-11.5 \times 3.2-6 \mu \mathrm{m}$, Pegler 1977 as L. angiospermarum Singer), South Africa (6.2-9 × 4.2-5 $\mu$ m, Reid \& Eicker 1998), Sri Lanka (7.5-9.5 × 3.5-5 $\mu \mathrm{m}$, Pegler 1986) and Brazil (7.5-11 × 4.2-5 $\mu \mathrm{m}$, Cortez \& Sulzbacher 2009). Lactocollybia microspora and L. aequatoriales differ from L. epia in having ellipsoid spores. Lactocollybia piliicystis D.A. Reid \& Eicker and L. variicystis D.A. Reid \& Eicker closely resemble L. epia in growth habit and having small amygdaliform spores. However, L. epia microscopically differs from the formers in having cylindrico-clavate cheilocystidia rather than lageniform cheilocystidia with long neck. Lactocollybia epia is being reported for the first time from Western Ghats of Karnataka.

Known distribution - Kerala, Wayanad, Begur, Kuruva; Thirunelli, Brahmagiri (Mohanan 2011); Maharashtra, Pune, Pune University Campus; Agarkar Research Institute Campus; Mulshi (Senthilarasu 2014); UtTaR PradeSH, Varanasi (Tewari \& Singh 1973 as L. angiospermarum). 


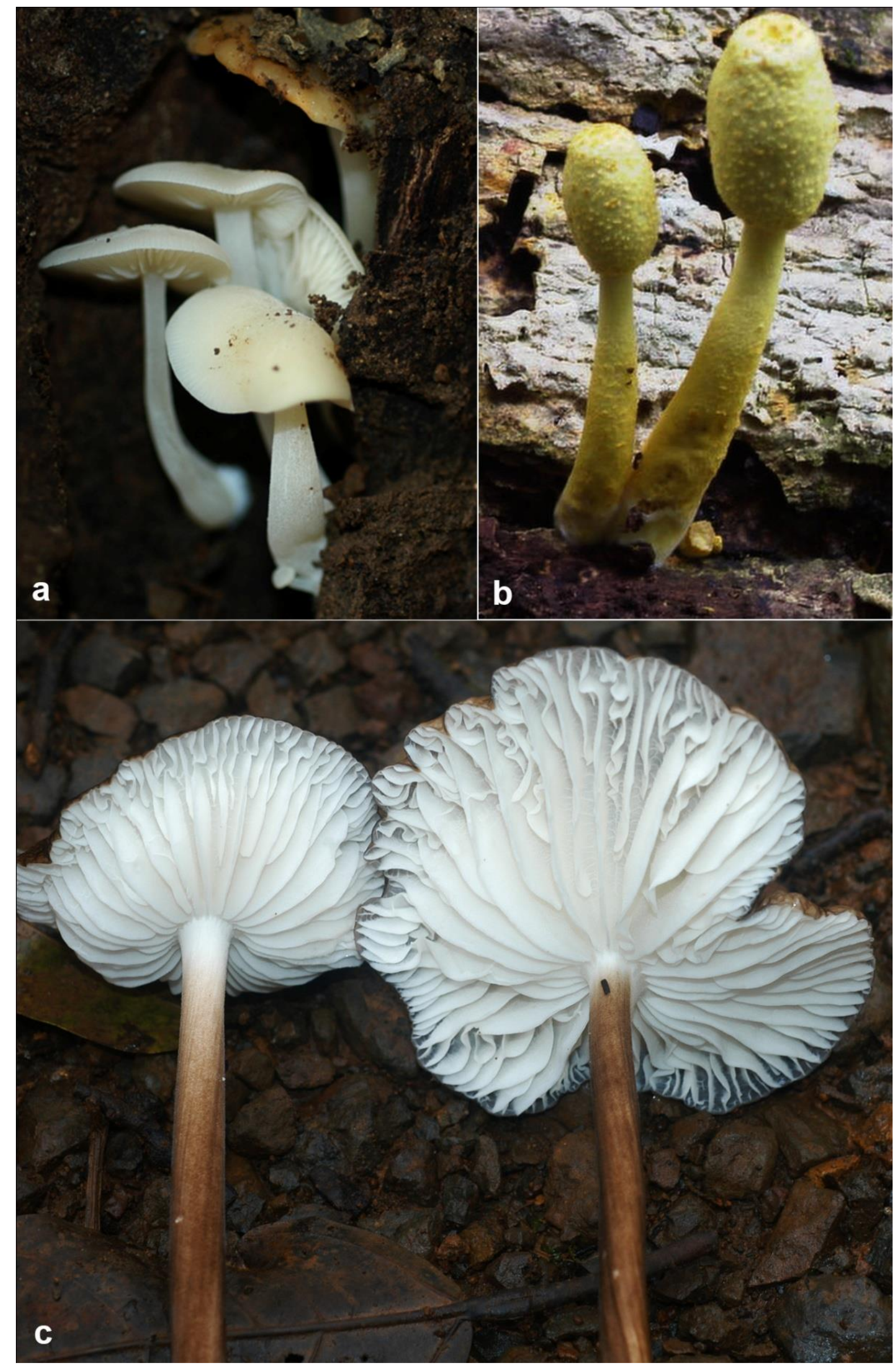

Fig. 3 - Basidiomes in their natural habitat. a, Lactocollybia epia. b, Leucocoprinus birnbaumii. c, Oudemansiella furfuracea. 
Pileus 20-35 mm diam., ovoid then conical; surface prime butter yellow (4A5) at the disc, prime rose yellow (1A6) elsewhere, bearing loose scattered, deep yellow (1A6) floccose squamules; margin thin, sulcate striate, half-way to the disc. Lamellae free, sulphur yellow (1A5), crowded, with lamellulae of different lengths. Stipe 70-95 $\times 7-9 \mathrm{~mm}$, cylindric, expanding to clavate bulbous base $\leq 10 \mathrm{~mm}$ diam.; surface concolorous with the pileus, smooth. Annulus membranous, fugacious. Context thin, concolorous with the pileus. Basidiospores $(9.8 \pm 0.8 \times 6.2 \pm 0.3),(8) 9-10(11) \times 5.5-$ $7(7.5) \mu \mathrm{m}, \mathrm{Q}=1.58$, ellipsoid, truncated at the apex by a small but distinct germ pore, hyaline, dextrinoid, strongly metachromatic, with a complex wall.

Specimens examined - India, Karnataka State, Kodagu district, Uppangala Forest, on wood, solitary, scattered, 8 June 2002, coll. Senthil. (Herb. MUBL No. 3473).

Notes - Leucocoprinus birnbaumii that grows on buried wood in soil or well decayed wood can easily be distinguished in the forest by small to medium sized, bright yellow basidiomes covered by concolorous, minute, flocculose squamules. Leucocoprinus birnbaumii is a common species distributed throughout the tropical and subtropical regions. Leucocoprinus straminellus (Bagl.) Narducci \& Caroti resembles L. birnbaumii in having similar sized and coloured basidiomes (light yellow pileus with concolorous stipe), however, the former differs from L. birnbaumii in having smaller basidiospores without germ pore and the pileus covering by globose elements rather than a repent epicutis of radially arranged, parallel, thin-walled, branched chains of, hyaline hyphal elements as in L. birnbaumii. Another yellow species Leucoagaricus sulphurellus (Pegler) Akers (Akers et al. 2000) earlier described as Leucocoprinus sulphurellus Pegler that morphologically resembles $L$. birnbaumii can be distinguished by yellow pileus lacking sulcate striate margin, pileus and gills that become blue to green on bruising, and ellipsoid to ovoid, weakly dextrinoid, smaller basidiospores $(5.1-6.5 \times 3.8-4.3 \mu \mathrm{m}$, Akers et al. 2000) with small germ pore.

Known distribution - ANDHRA PRADESH, Krishna, Machilipatnam [Berkeley 1867 as Agaricus allicinus Schumach. (as allicens)]; KARNATAKA, Bangalore, Janabharathi (Pushpa \& Purushothama 2011, 2012); Dakshina Kannada, Mangalore, cashew plantation (Karun \& Sridhar 2014); KerALA, Ernakulam, Perumbavoor, Iringole Kavu; Wayanad, Brahmagiri (Mohanan 2011); Calicut, Puthiyangadi; Wayanad, Kalpetta; Malappuram, Calicut University Campus (Kumar \& Manimohan 2009); Malappuram; Ernakulam; Thiruvananthapuram; Kozhikode; Wayanad; Idukki; Kollam (Sankaran \& Florence 1995, Vrinda et al. 2003, Florence 2004, Vrinda \& Pradeep 2011); Maharashtra, Pune, Pune University Campus (Senthilarsu 2014); Odisha, Cuttack (Dhancholia \& Sinha 1990); TAMIL NADU, Chennai (Natarajan 1977 as Leucocoprinus cepaestipes (Sowerby) Pat.); Tambaram, Madras Christian College Campus, Raj Bhavan Campus (Natarajan \& Manjula 1981); Uttar Pradesh, Saharanpur (Hennings 1901 as Lepiota cepaestipes var. lutea (Bolton) Sacc.); WeST Bengal, South 24 Pargana, Kumirmari Island (Dutta et al. 2011); Sundarbans mangrove forest (Dutta et al. 2013); lateritic region of West Bengal (Pradhan et al. 2013).

Oudemansiella furfuracea (Peck) Zhu L. Yang, G.M. Muell., G. Kost \& Rexer, Mycosystema, 28(1): 7 (2009)

Fig. 3c

Pileus 30-120 mm diam., plane, broadly subumbonate; surface camel brown (6C4) at the center, light brown (6D8) elsewhere, viscid, smooth; margin regular, translucent striate. Lamellae adnate with decurrent tooth, $\leq 10 \mathrm{~mm}$ broad, whitish, moderately spaced with lamellulae of four lengths; edge concolorous, smooth. Stipe 100-350 × 5-15 mm, cylindric, equal, hollow; surface leather brown (6E6) above, whitish below, longitudinally striate, pruinate, with a tapering, subterranean, pseudorrhiza $\geq 70 \mathrm{~mm}$ long. Context thick, $\leq 5 \mathrm{~mm}$ broad, whitish. Basidiospores $(14.1 \pm 0.9 \times 11.1 \pm 0.8),(12.5) 13.5-15(16.5) \times(9) 10-12.5(13) \mu \mathrm{m}, \mathrm{Q}=1.2$, broadly ellipsoid, hyaline, smooth, with slightly thickened wall, containing a single large oil guttule.

Specimens examined - India, Karnataka State, Kodagu district, Uppangala Forest, on ground, solitary to scattered, 21 June 2001, coll. Senthil. (Herb. MUBL 3438), 11 August 2010, (MCI 1379).

Notes - The Xerula-Oudemansiella complex has been phenotypically and phylogenetically critically rearranged in recent years (Wang et al. 2008, Yang et al 2009, Petersen \& Hughes 2010). Initially, only three genera, Oudemansiella Speg. (Spegazzini 1881), Mucidula Pat. (Patouillard 
1887) and Xerula Maire (Maire 1933) were proposed for Xerula-Oudemansiella complex based on Agaricus platensis Speg., A. mucidus Schrad.: Fr. and A. longipes Bull., respectively. Later, Moser (1955) merged Mucidula and Xerula into Oudemansiella and this assessment was followed by several authors who treated Xerula as a subgenus/section under Oudemansiella (Clémençon 1979, Singer 1986, Pegler \& Young 1987, Rexer \& Kost 1989a, b, Yang \& Zang 1993, Yang 2000, Mizuta 2006). However, Dörfelt $(1979,1980 a, 1980 b, 1981,1983,1984)$ elevated Xerula to generic level and retained Oudemansiella and Xerula as separate genera. Further, he significantly emended the genus Xerula and several species from Oudemansiella were transferred to Xerula. This concept was adopted by several mycologists (Boekhout \& Bas 1986, Redhead et al. 1987, Petersen \& Halling 1993, Petersen \& Methven 1994, Corner 1994, 1996, Boekhout 1999, Halling \& Mueller 1999, Contu 2000, Petersen 2000, Mueller et al. 2001, Petersen \& Hughes 2005, Horak 2005, Petersen \& Nagasawa 2006, Petersen \& Baroni 2007, Petersen 2008a, 2008b, 2008c).

Recent phylogenetic analysis also confirmed that Xerula and Oudemansiella are separate genera. Further, the sections of Oudemansiella were critically reviewed (Wang et al. 2008, Yang et al. 2009, Petersen \& Hughes 2010). Petersen \& Hughes (2010) proposed eight genera including four new genera Ponticulomyces R.H. Petersen, Hymenopellis R.H. Petersen, Protoxerula R.H. Petersen, Paraxerula R.H. Petersen, Dactylosporina (Clémençon) Dörfelt, Mucidula Pat., Oudemansiella Speg. and Xerula Maire based on morphological and molecular analysis. However, Vellinga (2010) stated that "recognition of non-monophyletic genera are problematic". The recent phylogenetic analysis (Hao et al. 2014, Qin et al. 2014) also confirmed that Xerula, Paraxerula, Oudemansiella (comprising of Ponticulomyces, Hymenopellis, Protoxerula, Dactylosporina, Mucidula and Cribbea A.H. Sm. \& D.A. Reid) and a recently described new genus, Cibaomyces Zhu L. Yang, Y.J. Hao \& J. Qin (Hao et al. 2014) are distinct genera. As a result of all these studies the species of Oudemansiella-Xerula complex are distributed in Xerula s.str., Paraxerula, Oudemansiella s.1 and Cibaomyces. Therefore, in this study, the present species is assigned as Oudemansiella furfuracea rather than Hymenopellis furfuracea (Peck) R.H. Petersen.

Oudemansiella furfuracea grows in caespitose or solitary to scattered on buried dead wood and is characterized by visid pileus, long radicated, furfuraceous stipe, lacking annulus, smooth spores, and ixohymeniderm pileipellis that lacking pileocystidia. The very closest taxon Oudemansiella radicata (Relhan) Singer differs from $O$. furfuracea in having smooth stipe.

Known distribution - KeRALA, Thrissur, Peechi; Munnar, Pambadumshola (Mohanan 2011 as Xerula furfuracea (Peck) Redhead, Ginns \& Shoemaker).

Termitomyces clypeatus R. Heim, Bull. Jard. Bot. État Brux. 21: 207 (1951)

Fig. $4 \mathrm{a}$

Pileus 50-70 mm diam., convex, with central, prominent, spiniform perforatorium; surface dark brown (6F7) at the center, cinnamon brown (6D6) elsewhere, dry, smooth, glabrous; margin decurved, entire, soon radially cracked, exposing white context. Lamellae free, $\leq 8 \mathrm{~mm}$ broad, white, crowded with lamellulae of different lengths. Stipe 70-125 ×8-10 mm; surface white, smooth, solid, cylindric, expanding below with swollen base, 15-20 mm diam., radicated, pseudorrhiza well developed. Annulus absent. Context $\leq 9 \mathrm{~mm}$ thick at the disc. Basidiospores $(7.1 \pm 0.71 \times 4.4 \pm 0.47)$, (5)6-7.5(8) $\times(3.5) 4-4.6(5) \mu \mathrm{m}, \mathrm{Q}=1.58$, short ellipsoid, smooth, hyaline, inamyloid, thin-walled, with a single large guttule.

Specimens examined - India, Karnataka State, Kodagu district, Manaduka Forest, on ground, solitary, 23 June 2001, coll. Senthil. (Herb. MUBL 3457), Uppangala Forest, 11 August 2010, (MCI 1384).

Notes - The characteristic features of the present collection are the medium sized basidiomes having brownish, smooth, glabrous pileus with sharp spiniform perforatorium at the disc, and smooth stipe with long hypogeal white pseudorrhiza. The species of Termitomyces are mainly differed by their morphological characters. Termitomyces clypeatus phenotypically closely resembles the other Termitomyces species T. heimii Natarajan, T. mammiformis R. Heim, T. aurantiacus (R. Heim) R. Heim and T. striatus (Beeli) R. Heim in having medium sized basidiomes (pileus $>50$ to $<100 \mathrm{~mm}$ diam.) with white to cream to pale greyish pseudorhiza. However, T. striatus has white to cream to greyish white pileus, and $T$. aurantiacus has golden orange to reddish brown pileus. Termitomyces 
heimii and T. mammiformis differ from T. clypeatus in having squamulose pileus and stipe, persistent, double ringed annulus and leathery, hollow pseudorhiza. Further T. heimii has coarse, obtuse perforatorium, and $T$. mammiformis has scrobiculate, mammiform perforatorium, whereas, $T$. clypeatus has smooth, spiniform perforatorium.

Known distribution - KARNATAKA, Bangalore (Pushpa \& Purushothama 2012); Dakshina Kannada, Mangalore, Konaje village, Areca plantations; Kodagu, B'Shettigeri; V. Badaga; Kottoli; Mythadi; Virajpet (Pahlevanlo \& Janardhana 2012, Karun \& Sridhar 2013); KeRALA, Nilambur, Chandhakkunnu; Trissur, Peechi and Kuthiran; Palode, Arippa; Wayanad, Bavali road (Mohanan 2011); Malappuram; Trissur; Kollam; Wayanad; Thiruvananthapuram; Ernakulam; Palakkad (Leelavathy et al. 1983, Pradeep \& Vrinda 2007, Varghese et al. 2010); HimaChal PradeSH, Solan (Sharma et al. 1977); MAHARASHTRA, Kanakeshwar (Patil et al. 1979); TAMIL NAdU, Chennai, Madras University Campus (Natarajan 1975); WeST BENGAL (Pradhan et al. 2012, Dutta \& Acharya 2014); Sundarbans mangrove forest (Dutta et al. 2013); Santiniketan (Bhattacharya et al. 1986); lateritic region of West Bengal (Pradhan et al. 2013).

Termitomyces microcarpus (Berk. \& Broome) R. Heim, Arch. Mus. Hist. Nat. Paris, ser. 6 18: 128 (1942)

Fig. $4 \mathrm{~b}$

Pileus 5-19 mm diam., initially conic, 7-9 mm high, becoming convex, finally applanate, often umbonate with a papillate projection; surface yellowish white (4A2) at the disc, white elsewhere, smooth, glabrous; margin decurved, soon plane, crisped, becoming rimose to eroded with age. Lamellae adnexed, white, $\leq 1 \mathrm{~mm}$ wide near the disc, moderately crowded with lamellulae of different lengths. Stipe 60-80 × 1-2 mm, cylindric, slightly tapering towards apex, solid, slender, lacking pseudorhiza; surface white to yellowish white (4A2), smooth, glabrous. Annulus absent. Context thin, $\leq 1 \mathrm{~mm}$ thick at the disc. Basidiospores $(5.4 \pm 0.4 \times 3.5 \pm 0.3),(4.5) 5-5.5(6) \times 3-3.5(4.5)$ $\mu \mathrm{m}, \mathrm{Q}=1.54$ short ellipsoid, smooth, hyaline, thin-walled, with a single large guttule.

Collections examined - India, Karnataka, Kodagu district, Manaduka Forest, soil, gregarious to caespitose, June 2002, Senthil. (MUBL 3458), Uttara Kannada, Sirsi, December 2012, (MCI 1387).

Notes - Termitomyces microcarpus is one of the smallest species in the genus Termitomyces growing gregariously and can be distinguished by white basidiomes having papillate projection at the disc and lacking long, hypogeal pseudorhiza. Termitomyces microcarpus closely resembles T. medius R. Heim \& Grassé, T. entolomoides R. Heim, T. radicatus Natarajan and T. tylerianus Otieno in having similar sized, small basidiomes (5-35(45) mm diam. pileus). However, T. microcarpus differs from its closest allies in lacking long hypogeal pseudorhiza. In addition, T. medius has grayish cream pileus, $T$. tylerianus has yellow to pale yellow pileus with brown center, $T$. radicatus (Natarajan 1977) has orange white to orange grey pileus with brown perforatorium and T. entolomoides has blackish grey center with bluish tinted pileus.

Known distribution - ANDHRA Pradesh, Nellore (Pegler \& Vanhaecke 1994); GuJARAT (Lahiri et al. 2010); Himachal Pradesh, Kasuli (Pegler \& Vanhaecke 1994, Kumari et al. 2012); KARnATAKA, Bangalore (Pushpa \& Purushothama 2012); Kodagu, Sampaje; Kottoli; Bramhagiri wild life sanctuary; Dubare (Karun \& Sridhar 2013); KerALA, Nilambur, Chandakkunnu; Thrissur, Peechi; Kuthiran; Wadakkancherry, Potta (Mohanan 2011); Ernakulam; Trissur; Malappuram; Idukki; Thiruvananthapuram, Vellayani; Kollam; Wayanad (Sathe \& Daniel 1980 as Podabrella microcarpa (Berk. \& Broome) Singer, Leelavathy et al. 1983, Pegler \& Vanhaecke 1994, Sankaran \& Florence 1995, Florence \& Yesodharan 1997, 2000, Mohanan 2003, Florence 2004, Pradeep \& Vrinda 2007, Varghese et al. 2010); Madhya Pradesh, Gwalior (Chaubey et al. 2010); MaHARASHTRA, Pune (Patil et al. 1979); Agharkar Research Institute Campus (Senthilarasu 2014); Thane; Sindhudurg; Ratnagiri (Borkar et al. 2015); MEghalaya, Shillong, Bishupur (Pegler \& Vanhaecke 1994); PunJAB, Chandigarh (Rawla et al. 1983, as T. microcarpus f. santalensis R. Heim); Ludiana (Pegler \& Vanhaecke 1994); Patiala, Punjabi University Campus (Atri et al. 1995); TAMIL NADU, Chennai, Madras University Campus (Natarajan 1975); Tirunelveli, Mundanthurai sanctuary (Natarajan \& Raman 1981 as T. microcarpus f. elongatus R. Heim), Villupuram, Pichandikulam Forest (Mani \& Kumaresan 2009 as Termitomyces sp. 2); Kanyakumari, Vellambi 
hills (Sargunam et al. 2012); TrIPURA, Agartala (Pegler \& Vanhaecke 1994); Uttarakhand, Pauri; Kanda; Dehradun (Semwal et al. 2014); WeST BENGaL, (Pradhan et al. 2012, Dutta \& Acharya 2014); Sundarbans mangrove forest (Dutta et al. 2013); Santiniketan (Bhattacharya et al. 1986); lateritic region of West Bengal (Pradhan et al. 2013).

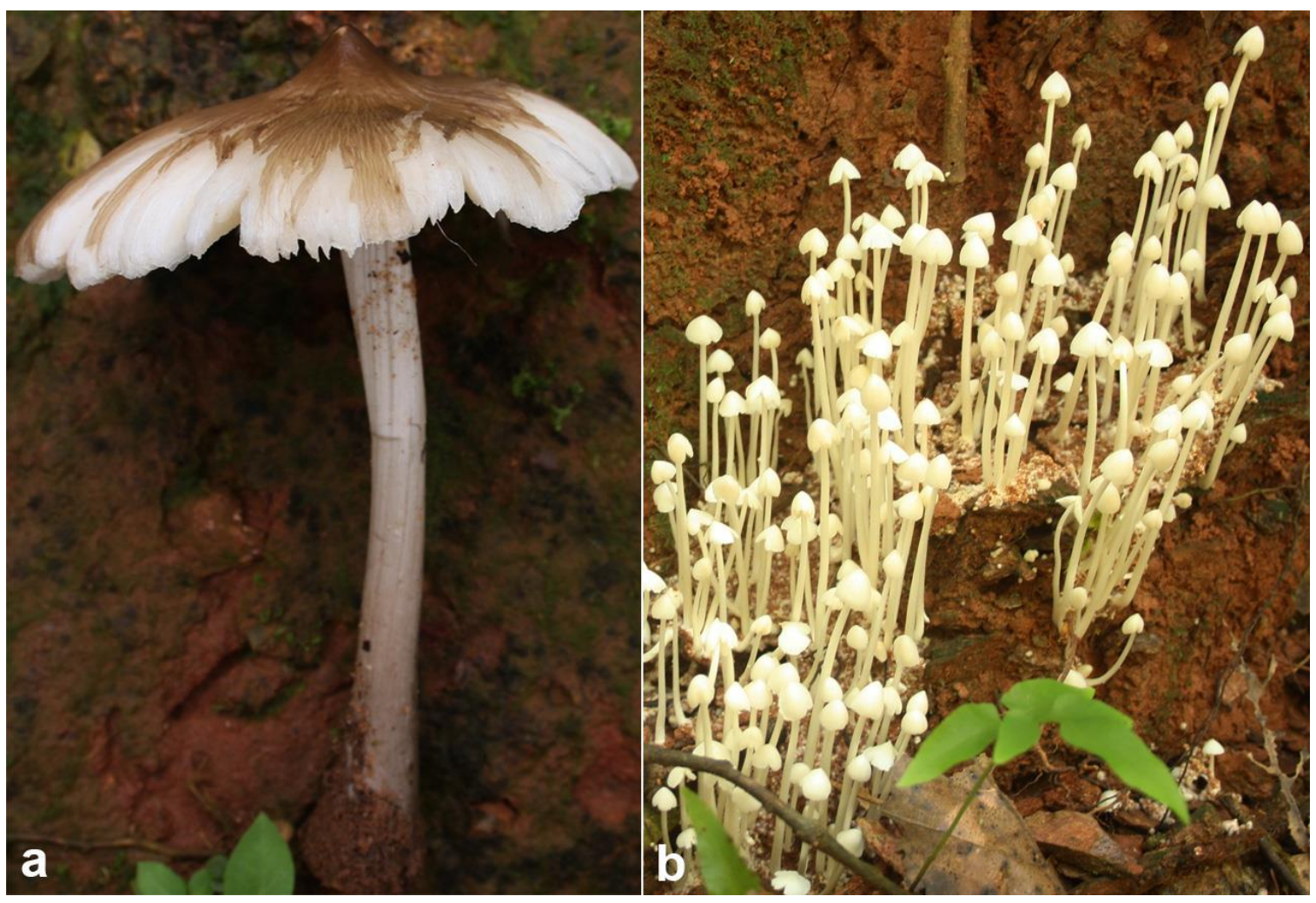

Fig. 4 - Basidiomes in their natural habitat. a -Termitomyces clypeatus. b, T. microcarpus.

Table List of gilled fungi reported from Western Ghats of Karnataka

\begin{tabular}{|c|c|c|c|c|}
\hline \multirow{2}{*}{$\begin{array}{l}\text { Order/Family/Species } \\
\text { Agaricales Underw. }\end{array}$} & \multirow[t]{2}{*}{ Place of collection } & \multicolumn{3}{|l|}{ Reference } \\
\hline & & \multicolumn{3}{|c|}{ Agaricaceae Chevall. } \\
\hline Agaricus bambusophilus Heinem. & Jodpala, Kodagu & $\begin{array}{l}\text { Natarajan } \\
(1994 / 1995)\end{array}$ & $\&$ & Purushothama \\
\hline $\begin{array}{l}\text { A. heinemanniensis K. Natarajan \& } \\
\text { Purush. }\end{array}$ & Merkanja, Sullia & $\begin{array}{l}\text { Natarajan } \\
(1994 / 1995)\end{array}$ & $\&$ & Purushothama \\
\hline A. osecanus Pilát & Jodpala, Kodagu & $\begin{array}{l}\text { Natarajan } \\
(1994 / 1995) \\
\text { Møller }\end{array}$ & $\begin{array}{l}\& \\
\text { as } A .\end{array}$ & $\begin{array}{l}\text { Purushothama } \\
\text { nivescens F.H. }\end{array}$ \\
\hline A. ustulatus With. & Merkanja, Sullia & $\begin{array}{l}\text { Natarajan } \\
(1994 / 1995)\end{array}$ & $\&$ & Purushothama \\
\hline $\begin{array}{l}\text { Chlorophyllum bharatense Sathe \& } \\
\text { S.M. Kulk. }\end{array}$ & Londa & \multicolumn{3}{|c|}{ Sathe \& Kulkarni 1980} \\
\hline C. rachodes (Vittad.) Vellinga & Shimoga & \multicolumn{3}{|c|}{$\begin{array}{l}\text { Swapna et al. } 2008 \text { as Macrolepiota } \\
\text { rachodes (Vittad.) Singer } \\
\text { (Macrolepiota rhacodes O.V.) }\end{array}$} \\
\hline $\begin{array}{l}\text { C. shimogaense Sathe \& S.M. } \\
\text { Kulk. }\end{array}$ & Shimoga & \multicolumn{3}{|c|}{ Sathe \& Kulkarni 1980} \\
\hline Coprinus calyptratus Peck & Shimoga & \multicolumn{3}{|c|}{ Swapna et al. 2008} \\
\hline C. sterquilinus (Fr.) Fr. & Shimoga & \multicolumn{3}{|c|}{ Swapna et al. 2008} \\
\hline $\begin{array}{l}\text { Coprinopsis patouillardii (Quél.) } \\
\text { G. Moreno }\end{array}$ & Heggala-Thora, Virajpet, Kodagu & \multicolumn{3}{|c|}{$\begin{array}{l}\text { Karun \& Sridhar } 2015 \text { as Coprinus } \\
\text { patouillardii Quél. }\end{array}$} \\
\hline Cystolepiota seminuda (Lasch) & Shimoga & \multicolumn{3}{|c|}{ Swapna et al. 2008} \\
\hline
\end{tabular}




\begin{tabular}{|c|c|c|}
\hline Order/Family/Species & Place of collection & Reference \\
\hline \multicolumn{3}{|l|}{ Bon } \\
\hline $\begin{array}{l}\text { Lepiota citrophylloides Sathe \& } \\
\text { S.M. Kulk. }\end{array}$ & Castle rock & Sathe \& Kulkarni 1980 \\
\hline $\begin{array}{l}\text { Leucoagaricus variisporus Sathe \& } \\
\text { S.M. Kulk. }\end{array}$ & Baghmandla & Sathe \& Kulkarni 1980 \\
\hline $\begin{array}{l}\text { L. sublittoralis (Kühner ex Hora) } \\
\text { Singer }\end{array}$ & Londa & $\begin{array}{l}\text { Sathe \& Kulkarni } 1980 \text { as } \\
\text { Leucoagaricus wichanskyi var. } \\
\text { macrospora } \text { Sathe \& S.M. Kulk. }\end{array}$ \\
\hline $\begin{array}{l}\text { Leucocoprinus cretaceus (Bull.) } \\
\text { Locq. }\end{array}$ & Shimoga & S \\
\hline $\begin{array}{l}\text { L. fragilissimus (Ravenel ex Berk. } \\
\text { M.A. Curtis) Pat. }\end{array}$ & Agumbe & Sathe \& Kulkarni 1980 \\
\hline $\begin{array}{l}\text { Macrolepiota procera (Scop.) } \\
\text { Singer }\end{array}$ & Londa & Sathe \& Kulkarni 1980 \\
\hline $\begin{array}{l}\text { Micropsalliota } \\
\text { Heinem. }\end{array}$ & Guthigar, Suillia & $\begin{array}{l}\text { Natarajan } \\
(1994 / 1995)\end{array} \quad \& \quad$ Purushothama \\
\hline $\begin{array}{l}\text { M. bambusicola (Heinem.) } \\
\text { Heinem. }\end{array}$ & Kodagu & $\begin{array}{l}\text { Natarajan } \\
(1994 / 1995)\end{array} \quad \& \quad$ Purushothama \\
\hline M. brunneola Heinem. & Jodpala, Kodagu & $\begin{array}{l}\text { Natarajan } \\
(1994 / 1995)\end{array} \quad \& \quad$ Purushothama \\
\hline \multirow{2}{*}{$\begin{array}{l}\text { M. brunneosperma (Singer) Pegler } \\
\text { M. subarginea Heinem. }\end{array}$} & Londa & Sathe \& Kulkarni 1980 \\
\hline & Madenadu, Mercara & $\begin{array}{l}\text { Natarajan } \\
(1994 / 1995)\end{array} \quad \& \quad P u$ \\
\hline \multicolumn{3}{|l|}{ Amanitaceae R. Heim ex Pouzar } \\
\hline $\begin{array}{l}\text { Amanita angustilamellata (Höhn.) } \\
\text { Boedijn }\end{array}$ & Uppangala Forest, Kodagu & $\begin{array}{l}\text { Natarajan et al. } 2005 \mathrm{~b} \text { as } A . \\
\text { vaginata (Bull.) Lam. }\end{array}$ \\
\hline A. antillana Dennis & Uppangala Forest & \multirow{2}{*}{$\begin{array}{l}\text { Natarajan et al. } 2005 \mathrm{~b} \\
\text { Natarajan et al. } 2005 \mathrm{~b} \text { as } \text { A. cinerea } \\
\text { Bres. }\end{array}$} \\
\hline \multirow{2}{*}{$\begin{array}{l}\text { A. bresadolana Neville \& } \\
\text { Poumarat } \\
\text { A. hemibapha (Berk. \& Broome) } \\
\text { Sacc. }\end{array}$} & Uppangala Forest & \\
\hline & Manaduka & $\begin{array}{l}\text { Natarajan et al. 2005b as } A . \\
\text { hemibapha var. cystidiosa }\end{array}$ \\
\hline $\begin{array}{l}\text { A. sampajensis Sathe \& S.M. Kulk. } \\
\text { Bolbitiaceae Singer }\end{array}$ & Sampaje & Sathe \& Kulkarni 1980 \\
\hline \multirow{3}{*}{$\begin{array}{l}\text { Conocybe pubescens (Gillet) } \\
\text { Kuhner } \\
\text { Cortinariaceae R. Heim ex Pouzar } \\
\text { Cortinarius causticus } \text { Fr. }\end{array}$} & $\begin{array}{l}\text { Makutta Reserve forest, Virajpet, } \\
\text { Kodagu }\end{array}$ & Karun \& Sridhar 2015 \\
\hline & & \\
\hline & Uppangala Forest & \multirow{2}{*}{$\begin{array}{l}\text { Natarajan et al. } 2005 \mathrm{~b} \\
\text { Natarajan et al. } 2005 \mathrm{~b} \text { as Anamika } \\
\text { indica K.A. Thomas, Paintner, } \\
\text { M.M. Moser \& Manim. }\end{array}$} \\
\hline $\begin{array}{l}\text { Hebeloma indicum (K.A. Thomas, } \\
\text { Peintner, M.M. Moser \& } \\
\text { Manim.) B.J. Rees }\end{array}$ & Uppangala Forest & \\
\hline Entolomataceae Kotl. \& Pouzar & & \\
\hline $\begin{array}{l}\text { Eccilia excentrica Natarajan \& } \\
\text { Purush. }\end{array}$ & Guthigar, Suillia; Jodpala, Kodagu & Natarajan \& Purushothama 1989 \\
\hline Entoloma cuboideum Hesler & Uppangala Forest, Kodagu & Senthilarasu \& Natarajan 2003 \\
\hline E. elevatum Corner \& E. Horak & Uppangala Forest, Kodagu & Senthilarasu \& Natarajan 2003 \\
\hline E. farlowii (Singer) Hesler & Manaduka, Kodagu & Senthilarasu \& Natarajan 2003 \\
\hline E. foetidum Hesler & Uppangala Forest, Kodagu & Senthilarasu \& Natarajan 2003 \\
\hline E. grayanum (Peck) Sacc. & Uppangala Forest, Kodagu & $\begin{array}{l}\text { Senthilarasu \& Natarajan } 2003 \text { as } \\
\text { E. grayanum var. grayanum (Peck) } \\
\text { Sacc. }\end{array}$ \\
\hline E. mephiticum (Murrill) Hesler & Uppangala Forest, Kodagu & Senthilarasu \& Natarajan 2003 \\
\hline $\begin{array}{l}\text { E. olorinum (Romagn. \& J. Favre) } \\
\text { Noordel. }\end{array}$ & Shimoga & $\begin{array}{l}\text { Swapna et al. } 2008 \text { as Entoloma } \\
\text { olonirum O.V. }\end{array}$ \\
\hline $\begin{array}{l}\text { E. vittalii Senthil., Kumaresan \& } \\
\text { S.K. Singh }\end{array}$ & Manaduka, Uppangala Forest & Senthilarasu et al. $2010 \mathrm{~b}$ \\
\hline $\begin{array}{l}\text { Hydnangiaceae Gäum. \& C.W. } \\
\text { Dodge }\end{array}$ & & \\
\hline Laccaria laccata (Scop.) Cooke & Guthigar, Merkanja, Suillia & $\begin{array}{l}\text { Natarajan \& Purushothama } 1986 \text { as } \\
\text { L. laccata var. pallidifolia (Peck) } \\
\text { Peck }\end{array}$ \\
\hline Hygrophoraceae Lotsy & & \\
\hline
\end{tabular}




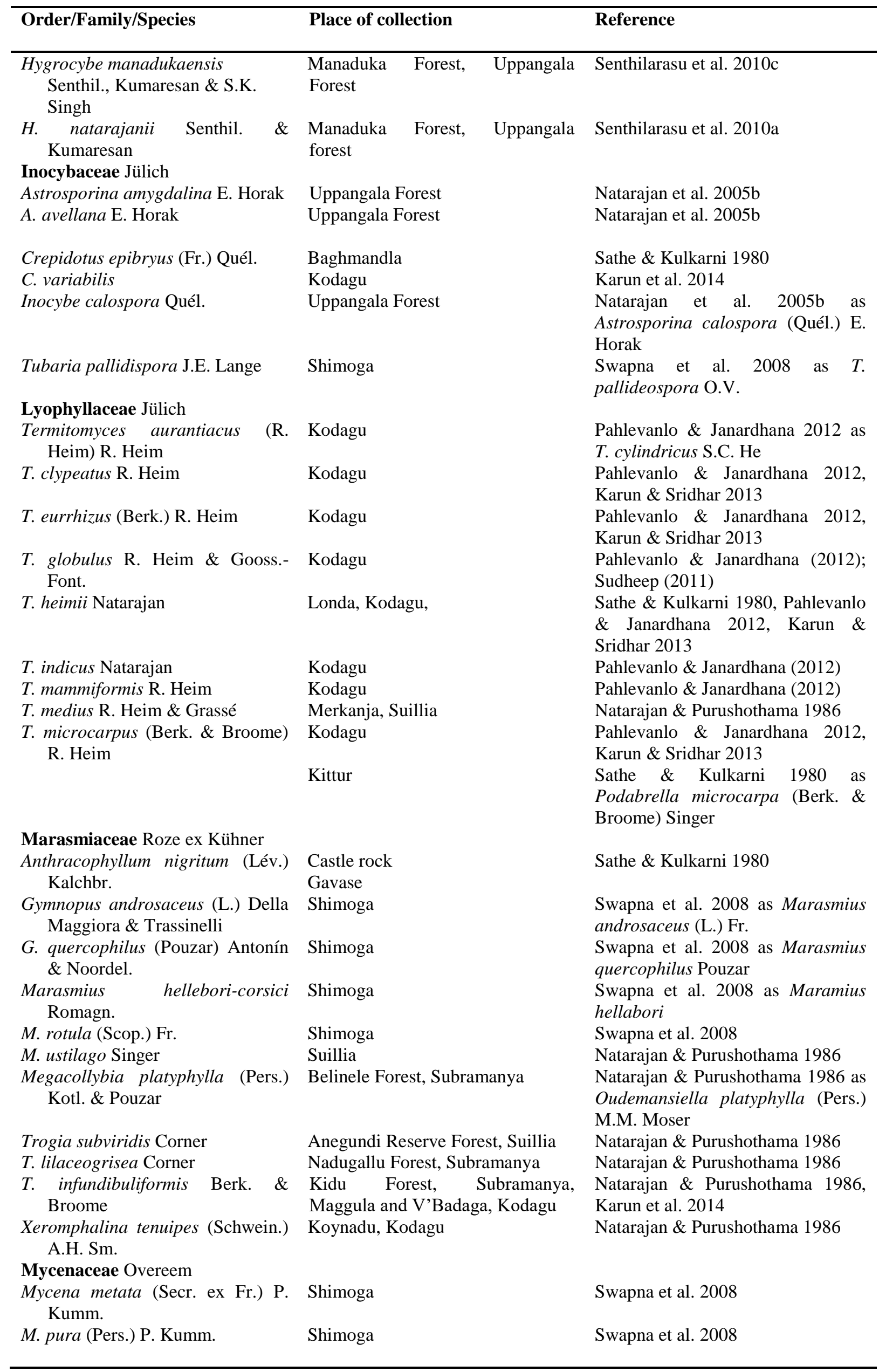




\begin{tabular}{|c|c|c|}
\hline Order/Family/Species & Place of collection & Reference \\
\hline \multicolumn{3}{|l|}{ Omphalotaceae Bresinsky } \\
\hline Marasmiellus musacearum Singer & Peraje, Kodagu & Natarajan \& Purushothama 1986 \\
\hline M. sanctae-marthae Singer & Merkanja, Suillia; Peraje, Kodagu & Natarajan \& Purushothama 1986 \\
\hline $\begin{array}{l}\text { M. troyanus (Murrill) Dennis } \\
\text { Physalacriaceae Corner }\end{array}$ & Merkanja, Suillia; Peraje, Kodagu & Natarajan \& Purushothama 1986 \\
\hline $\begin{array}{l}\text { Flammulina velutipes (Curtis) } \\
\text { Singer }\end{array}$ & Shimoga & Swapna et al. 2008 \\
\hline $\begin{array}{l}\text { Physalacria indica Chandrash. \& } \\
\text { Natarajan }\end{array}$ & Mercara & Chandrashekara \& Natarajan 1979 \\
\hline Xerula pudens (Pers.) Singer & Londa & $\begin{array}{l}\text { Sathe \& Kulkarni } 1980 \text { as } \\
\text { Oudemansiella longipes } \\
\text { Kumm.) M.M. Moser }\end{array}$ \\
\hline $\begin{array}{l}\text { Pleurotaceae Kühner } \\
\text { Hohenbuehelia nigra (Schwein.) } \\
\text { Singer }\end{array}$ & Kidu Forest, Subramanya & Natarajan \& Purushothama 1986 \\
\hline Pleurotus euosmus (Berk.) Sacc. & Pattankudi & Sathe \& Kulkarni 1980 \\
\hline P. flabellatus Sacc. & Kodagu, Augumbe & Pegler 1976 \\
\hline P. ostreatus (Jacq.) P.Kumm. & $\begin{array}{l}\text { Agumbe } \\
\text { Shimoga }\end{array}$ & $\begin{array}{l}\text { Sathe \& Kulkarni } 1980 \\
\text { Swapna et al. } 2008\end{array}$ \\
\hline $\begin{array}{l}\text { P. pulmonarius } \\
\text { Pluteaceae Kotl. \& Pouzar }\end{array}$ & Kodagu & Karun et al. 2014 \\
\hline $\begin{array}{l}\text { Pluteus salmoneus Sathe \& S.M. } \\
\text { Kulk. }\end{array}$ & Castle rock & Sathe \& Kulkarni 1980 \\
\hline $\begin{array}{l}\text { Psathyrellaceae } \\
\text { Moncalvo \& Redhead }\end{array}$ & & \\
\hline $\begin{array}{l}\text { Coprinellus disseminatus (Pers.) } \\
\text { J.E. Lange }\end{array}$ & Sampaje, Shimoga & $\begin{array}{l}\text { Sathe \& Kulkarni 1980, Swapna et } \\
\text { al. } 2008 \text { as Coprinus disseminatus } \\
\text { (Pers.) Gray }\end{array}$ \\
\hline $\begin{array}{l}\text { C. micaceus (Bull.) Vilgalys, } \\
\text { Hopple \& Jacq. Johnson }\end{array}$ & Shimoga & $\begin{array}{l}\text { Swapna et al. } 2008 \text { as Coprinus } \\
\text { micaceus (Bull.) Fr. (as C. } \\
\text { micalius) O.V. }\end{array}$ \\
\hline $\begin{array}{l}\text { Parasola plicatilis (Curtis) } \\
\text { Redhead, Vilgalys \& Hopple }\end{array}$ & Shimoga & $\begin{array}{l}\text { Swapna et al. } 2008 \text { as Coprinus } \\
\text { plicatilis (Curtis) Fr. }\end{array}$ \\
\hline $\begin{array}{l}\text { Strophariaceae Singer \& A.H. } \\
\text { Sm. }\end{array}$ & & \\
\hline $\begin{array}{l}\text { Agrocybe karnatakensis Sathe \& } \\
\text { S.M. Kulk. }\end{array}$ & Londa & Sathe \& Kulkarni 1980 \\
\hline A. musicola Natarajan \& Purush. & Guthigar, Ajjavara, Suillia & Natarajan \& Purushothama 1989 \\
\hline $\begin{array}{l}\text { Gymnopilus braendlei } \\
\text { Hesler }\end{array}$ & Jodpala, Kodagu & Purushothama \& Natarajan 1989 \\
\hline G. earlei Murrill & Peraje, Kodagu & Purushothama \& Natarajan 1989 \\
\hline G. hispidus (Massee) Murrill & Koynadu, Kodagu & Purushothama \& Natarajan 1989 \\
\hline G. junonius & Kodagu & Karun et al. 2014 \\
\hline G. luteus (Peck) Hesler & Koynadu, Kodagu & Purushothama \& Natarajan 1989 \\
\hline G. palmicola Murrill & Nettana, Subramanya & Purushothama \& Natarajan 1989 \\
\hline $\begin{array}{l}\text { Melanotus phaeophyllus (Berk.) } \\
\text { Pilát }\end{array}$ & Sampaje & Sathe \& Kulkarni 1980 \\
\hline $\begin{array}{l}\text { Psilocybe coprophila (Bull.) P. } \\
\text { Kumm. }\end{array}$ & $\begin{array}{l}\text { Heggala-Thora, Virajpet, } \\
\text { Kodagu }\end{array}$ & Karun \& Sridhar 2015 \\
\hline P. fimetaria (P.D. Orton) Watling & $\begin{array}{l}\text { Heggala-Thora, Virajpet, } \\
\text { Kodagu }\end{array}$ & Karun \& Sridhar 2015 \\
\hline $\begin{array}{l}\text { Tricholomataceae R. Heim ex } \\
\text { Pouzar }\end{array}$ & & \\
\hline Clitocybe odora (Bull.) P. Kumm. & Shimoga & Swapna et al. 2008 \\
\hline C. rivulosa (Pers.) P. Kumm. & Shimoga & Swapna et al. 2008 \\
\hline Collybia purpureogrisea (Petch) & Sampaje & Sathe \& Kulkarni 1980 as \\
\hline Pegler & & $\begin{array}{l}\text { Marasmiellus } \quad \text { purpureoalbus } \\
\text { (Petch) Singer }\end{array}$ \\
\hline Hygroaster agumbensis Sathe \& & Agumbe & Sathe \& Kulkarni 1980 as $H$. \\
\hline
\end{tabular}




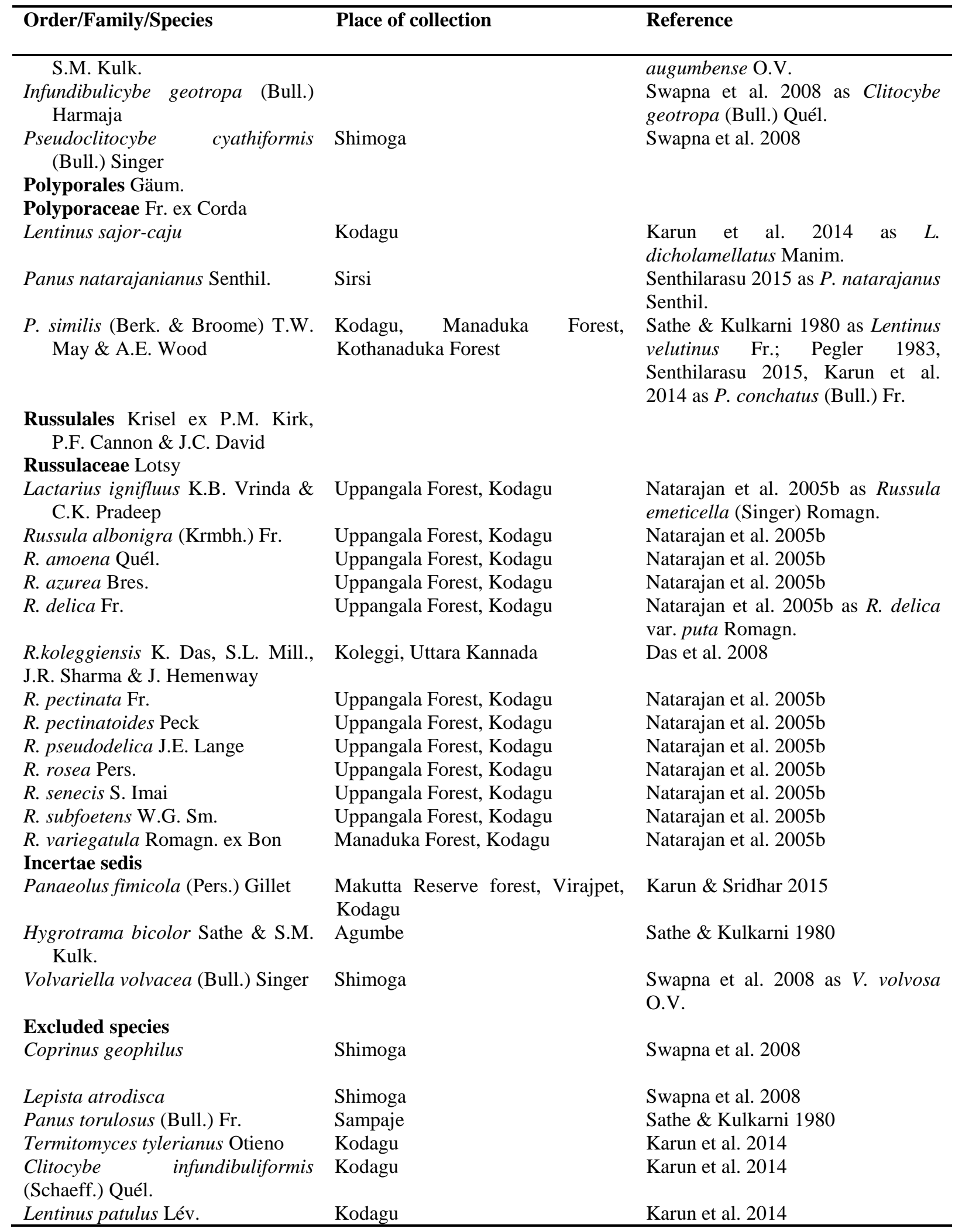

O.V. orthographic variant

\section{Discussion}

Fungal taxa that are documented and or newly described from Western Ghats reflect the mycodiversity of the tropics where this biota is one of the largest components. In this paper including the checklist, we present 132 agaric species in 60 genera belonging to Agaricales, Polyporales and Russulales collected and reported from Western Ghats and its foot hills of Karnataka State. Agaricales has the highest number of species (117) followed by Russulaes (13), whereas, Polyporales 
is represented by only three species. This agaric diversity in Karnataka region is similar with the recent agaric checklist of Kerala where 579 species of the 615 species reported belonging to Agaricales and 21 species to Russulales (Farook et al. 2013). Similarly, the highest number of agaric species have been reported in Agaricales (123) followed by Polyporales (4) and Russulales (3) from Maharashtra (Senthilarasu 2014). In Karnataka, higher numbers of species reported belong to Russula (12), followed by Termitomyces (9), and Entoloma (8). The genera Amanita, Hygrocybe and Micropsalliota are represented by five species each and Agaricus, Chlorophyllum and Pleurotus are represented by four species each. Around $58 \%$ genera are represented by only one species. However, the most species-rich genera in Kerala are Hygrocybe (41), Entoloma (41), Lepiota (39), Marasmius (27), Leucocoprinus (22) and Pluteus (22). Russula and Termitomyces are represented by 17 and 15 species respectively. About $7.1 \%$ of genera are represented by only one species (Farook et al. 2013). The most represented genera in Maharashtra are Agaricus (18) followed by Marasmius (13), Mycena (8), Lepiota (7), Pleurotus (6), Termitomyces (6), Amanita (5) and Inocybe (5). Around $13.2 \%$ genera are represented by only one species (Senthilarasu 2014). The highest numbers of new species have been described from Kerala (138) and Maharashtra (21) when compared to Karnataka where only 17 species have been described (Chandrasekara \& Natarajan 1979, Sathe \& Kulkarni 1980, Natarajan \& Purushothama 1986, 1989, 1994/1995, Reddy et al. 2005, Senthilarasu et al. 2010a,b,c, Senthilarasu 2015).

By compiling the two checklists (Farook et al. 2013, Senthilarasu 2014) with the present checklist, overall, 866 macrofungal species belonging to 133 genera in six Orders Agaricales, Boletales, Cantharellales, Gomphales, Polyporales and Russulales have been reported with Entoloma (53), Hygrocybe (45), Lepiota (44), Marasmius (39), Agaricus (36), Russula (28), Pluteus (24), Amanita (23), Inocybe (23), Leucocoprinus (23), Micropsalliota (23), Conocybe (20) and Leucoagaricus (20) the most species-rich genera. Most species have relatively narrow distribution ranges and, only $2 \%$ of species (25) have shown inter-state, wide distribution. The commonly distributed species in the three states are: Chlorophyllum molybdites, C. rachodes, Leucocoprinus birnbaumii, L. fragilissimus, Macrolepiota procera, Conocybe pubescens, Hygrocybe alwisii, $H$. astatogala, Termitomyces clypeatus, T. eurrhizus, T. heimii, T. mammiformis, T. microcarpus, Gymnopus androsaceus, Lactocollybia epia, Megacollybia platyplhylla, Trogia infundibuliformis, Oudemansiella furfuracea, Pleurotus flabellatus, P. ostreatus, Volvariella volvacea, Coprinus disseminatus, Cystoagaricus trisulphuratus, Parasola plicatilis and Lentinus sajor-caju (Table not provided). However, it can not be taken into account that the remaining species are geographically restricted. This paper indicates lack of significant mycological explorations, as well as the need for more long-term fungal studies in Western Ghats of Maharashtra and Karnataka where these specialized habitats are typically plant species-rich, and can also have a rich mycobiota of an extraordinary diversity or a habitat of rare species. Further, the ecological plasticity of the common species has to be investigated for better understanding of the ecological adaptations.

\section{Acknowledgements}

GS is indebted to the Director, SRM Research Instiute, SRM University for providing the laboratory facilities. Dr. Paromita Chakraborty is grately acknowledged for her encouragement and kind moral support. Sincere thanks to Dr. Wartchow and Mr. Jiang who provided the valuable literature for this study.

\section{References}

Akers BP, Angels SA, Kimbrough JW. 2000 - Leucoagaricus viridiflavoides, a new species from Florida, with notes on related taxa. Mycotax on 76(4), 39-50.

Atri NS, Kaur A, Saini SS. 2001 - Mushroom flora of Patiala. The genus Agaricus L. ex Fr. - Indian Journal of Mushrooms 19(1\&2), 1-9.

Atri NS, Kaur A. 2002 - Mushroom flora of Patiala. The genus Coprinus Pers. ex Gray. In "Plant diversity in India" (eds. JS Dargan and TA Sarma). Bishen Singh Mahendra Pal Singh, Dehra Dun, India. 
Atri NS, Saini SS, Kaur G. 1995 - Taxonomic studies on the North Indian agarics - the genus Termitomyces Heim. Mushroom Research 4, 7-10.

Bakshi BK. 1974 - Mycorrhizae and its role in forestry. Forest Research Institute, Dehra Dun.

Banerjee SN. 1947 - Fungus flora of Calcutta and suburbs 1. Bull. Bot. Soc. Beng. 1, 37-54.

Berkeley MJ. 1854 - Decades XLI-XLIII Indian Fungi. Hooker Journal of Botany 6, 129-143.

Berkeley MJ. 1867 - Fungi of the plains of India. Intell. Obser. 12, 18-21.

Bessette AE, Bessette AR, Fischer DW. 1997 - Mushrooms of Northeastern North America. Syracuse Univ. Press, Hong Kong.

Bhattacharya K, Roy A, Haldar P. 1986 - On the ecology of a termite hill at Santiniketan, West Bengal. Indian Journal of Mycological Research 24(2), 91-95.

Bhavanidevi S. 1998 - Agaricales of Kerala. In: Frontiers in Mushroom Research (eds TK Abraham, NS Pradeep, P Pushpangadan). Tropical Botanical Garden and Research Institute, Thiruvananthapuram, Kerala, 63-74.

Bhide VP, Pande A, Sathe AV, Rao VG, Patwardhan PG. 1987 - Fungi of Maharashtra (Supplement-I). Maharashtra Association for the Cultivation of Science, Research Institute, Pune $146 \mathrm{p}$.

Bi ZS, Zheng GY, Li TH, Wang YZ. 1993 - The Macrofungus Flora of China's Guangdong Province. Hongkong. The Chinese University Press, Hong Kong.

Boekhout T, Bas C - 1986. Notulae ad Floram Agaricinam Neerlandicam-XII. Some notes on the genera Oudemansiella and Xerula. Persoonia 13, 45-56.

Boekhout T. 1999 - Oudemansiella and Xerula. In: Bas C, Kuyper ThW, Noordeloos ME, Vellinga EC (eds.) Flora Agaricina Neerlandica 4. Rotterdam: A. A. Balkema Publishers. 177-178, 181-184.

Borkar P, Doshi A, Navathe S. 2015 - Mushroom diversity of Konkan region of Maharashtra, India. Journal of Threatened Taxa. 7(10), 7625-7640.

Bresadola G. 1920 - Synonymia et advotanda mycologia. Ann. Mycol. 14, 221-242.

Cesati V. de. 1879 - Mycetum in itinere Borneensi lectorum a cl. Od. Beccari. Atti Reale Accademia delle Scienze, Fisiche e Matematiche di Napoli 8(3), 1-28.

Chandrashekara KV, Natarajan K. 1979 - A new species of Physalacria from South India. Mycologia 71(1-6), 876-880. http://dx.doi.org/10.2307/3759208

Chaubey HS, Kumar S, Sharma YP. 2010 - The genus Termitomyces from Madhya Pradesh. Journal of Plant Development Sciences 2(1/2), 63-66.

Clémençon H. 1979 - Taxonomic structure of the genus Oudemansiella (Agaricales). Sydowia 32, 74-80.

Contu M. 2000 - IL Genere Xerula (Basidiomycotina, Agaricales) nell'Italia Centro-Meridionale de Insulare. Micologia e Vegetazione Mediterranea 15, 18-39.

Corner EJH. 1994 - On the agaric genera Hohenbuehelia and Oudemansiella Part II: Oudemansiella Speg. Gardens Bulletin Singapore 46, 49-75.

Corner EJH. 1996 - The agaric genera Marasmius, Chaetocalathus, Crinipellis, Heimiomyces, Resupinatus, Xerula and Xerulina in Malesia. Beiheft zur Nova Hedwigia 111, 1-175.

Cortez VG, da Silveira RMB. 2007 - Species of Hypholoma (Fr.) P. Kumm. (Strophariaceae, Agaricales) in Rio Grande do Sul State, Brazil. Acta. Bot. Bras. 21(3), 609-621.

Cortez VG, Sulzbacher eMA. 2009 - Lactocollybia epia (Basidiomycota): nova ocorrencia para o Rio Grande do Sul. Brazilian Journal of Biosciences 7(1), 9-13.

Das K, Miller SL, Sharma JR, Hemenway J. 2008 - Two new species of Russula from Western Ghats in India. Indian Journal of Forestry 31(3), 473-478.

Das K. 2009 - Mushrooms of Sikkim I: Barsey Rhododendron Sanctuary. Sikkim State Biodiversity Board, Botanical Survey of India.

Dhancholia S, Sinha MP. 1990 - Additional studies on agarics of Orissa II. Geobios new Reports 9, 108-113.

Dörfelt H. 1979 - Taxonomische Studien in der Gattung Xerula R. Mre. Feddes Repertorium 90, 363-388. http://dx.doi.org/10.1002/fedr.19790900504 
Dörfelt H. 1980a - Taxonomische Studien in der Gattung Xerula R. Mre. (II). Feddes Repertorium 91, 209-223. http://dx.doi.org/10.1002/fedr.19800910403

Dörfelt H. 1980b - Taxonomische Studien in der Gattung Xerula R. Mre. (III). Feddes Repertorium 91, 415-438. http://dx.doi.org/10.1002/fedr.19800910706

Dörfelt H. 1981 - Taxonomische Studien in der Gattung Xerula R. Mre. (V). Feddes Repertorium 92, 631-674. http://dx.doi.org/10.1002/fedr.19810920903

Dörfelt H. 1983 - Taxonomische Studien in der Gattung Xerula R. Mre. (VII). Feddes Repertorium 94, 251-62.

Dörfelt H. 1984 - Taxonomische Studien in der Gattung Xerula R. Mre. (IX). Feddes Repertorium 95, 189-200.

Dutta AK, Acharya K. 2014 - Traditional and ethno-medicinal knowledge of mushrooms in West Bengl, India. Asian Journal of Pharmaceutical and Clinical Research 7(4), 36-41.

Dutta AK, Pradhan P, Basu SK, Acharya K. 2013 - Macrofungal diversity and ecology of the mangrove ecosystem in the Indian part of Sundarbans. Biodiversity 14(4), 196-206. http://dx.doi.org/10.1080/14888386.2013.848824

Dutta AK, Pradhan S, Giri S, Roy A, Acharya K. 2011 - Leucocoprinus birnbaumii (Corda) Singer: An addition to macrofungal flora of West Bengal, India. Journal of Mycology and Plant Pathology 41(2), 316-318.

Farook AV, Khan SS, Manimohan P. 2013 - A checklist of agarics (gilled mushrooms) of Kerala State, India. Mycosphere 4(1), 97-131. http://dx.doi.org/10.5943/mycosphere/4/1/6

Florence EJM, Yesodharan K. 1997 - Status survey of macrofungal flora of Peechi-Vazhani wildlife sanctuary. In: Proceedings of Ninth Kerala Science Congress (ed PK Iyengar). STEC, Thiruvananthauram, 477-479.

Florence EJM, Yesodharan K. 2000 - Macrofungal flora of Peechi-Vazhani wildlife sanctuary. KFRI Research Report No. 191. Kerala Forest Research Institute, Peechi, Kerala, India.

Florence EJM. 2004 - Biodiversity Documentation for Kerala, Part 2: Microorganisms (Fungi). KFRI Handbook No.17. Kerala Forest Research Institute, Peechi, Kerala, India.

Ghate SD, Sridhar KR, Karun NC. 2014 - Macrofungi on the coastal sand dunes of south-western India. Mycosphere 5(1), 144-151. http://dx.doi.org/10.5943/mycosphere/5/1/6

Ghate SD, Sridhar KR. 2015 - Contribution to the knowledge on macrofungi in mangroves of southwest India. Plant Biosystems 1-10. http://dx.doi.org/10.1080/11263504.2014.994578

Ghosh RN, Pathak NC, Singh MS. 1976 - The genus Chlorophyllum in India. Indian Phytopathology 29, 50-53.

Ghosh RN, Pathak NC, Tiwari I. 1967 - Studies on Indian Agaricales. Indian Phytopathology 29, 237-242.

Greeshma AA, Sridhar KR, Pavithra M. 2015 - Macrofungi in the lateritic scrub jungles of southwestern India. Journal of Threatened Taxa 7(11), 7812-7820. http://dx.doi.org/10.11609/JoTT.04260.7812-20

Halling RE, Mueller GM. 1999 - A new species and a new record for the genus Xerula (Agaricales) from Costa Rica. Mycotaxon 71, 105-110.

Hao YJ, Qin J, Yang ZL. 2014 - Cibaomyces, a new genus of Physalacriaceae from East Asia. Phytotaxa 162 (4), 198-210. http://dx.doi.org/10.11646/phytotaxa.162.4.2

Hedawoo GB. 2010 - Wild mushroom flora from Amravati Regoin, Maharastra, India. Journal of Mycology and Plant Pathology 40(3), 441-444.

Hennings P. 1901 - Fungi Indiae Orientalis II. Hedwigia 40, 323-342.

Hesler LR, Smith AH. 1963 - North American species of Hygrophorus. University of Tennessee Press, Knoxville. http://dx.doi.org/10.5962/bhl.title.61976

Hesler LR, Smith AH. 1965 - North American Species of Crepidotus. Hafner Publishing Company, New York and London $126 \mathrm{p}$.

Horak E. 2005 - Röhrlinge und Blätterpilze in Europa. Elsevier GmbH, München 1-555.

Karun NC, Sridhar KR, Anu Appaiah KA. 2014 - Diversity and Distribution of Macrofungi in Kodagu Region (Western Ghats) - A Preliminary Account. In: Biodiversity in India, Volume 7 (Ed. Pullaiah, T., Karuppusamy, S. and Rani, S.). Regency Publications, New Delhi, 73-96. 
Karun NC, Sridhar KR. 2013 - Occurrence and distribution of Termitomyces (Basidiomycota, Agaricales) in the Western Ghats and on the west coast of India. Czech Mycology 65(2), 233254.

Karun NC, Sridhar KR. 2014 - A preliminary study on macrofungal diversity in an arboretum and three plantations of the southwest coast of India. Current Research in Environmental and Applied Mycology 4(2), 173-187.

Karun NC, Sridhar KR. 2015 - Elephant dung inhabiting fungi in the Western Ghats. Current Research in Environmental \& Applied Mycology 5(1), 60-69.

Kornerup A, Wanscher JH. 1978 - Methuen handbook of colour. 3rd ed. Eyre Methuen, London. 243 p.

Kumar TKA, Manimohan P. 2009 - The genera Leucoagaricus and Leucocoprinus (Agaricales, Basidiomycota) in Kerala State, India. Mycotaxon 108, 385-428. http://dx.doi.org/10.5248/108.385

Kumari B, Atri NS, Upadhyay RC. 2012 - Culinary status and sociobiology of termitophilous and lepiotoid mushrooms of North West India. World Journal of Agricultural Sciences 8(4), 415420.

Lahiri SS, Shukla MD, Shah MB, Modi HA. 2010 - Documentation and analysis of certain macrofungal traditional practices from Western-India (Gujarat). Ethnobotanical leaflets 14, 626-641.

Largent DL. 1977 - How to identify Mushrooms to genus I: Macroscopical Features. 1-85.

Leelavathy KM, Little Flower, Suja CP. 1983 - The genus Termitomyces in India. In: Indian Mushroom Science-II (eds TN Kaul, BM. Kapoor). CSIR, New Delhi, 402-407.

Leelavathy KM, Manimohan P, Arnolds EJM. 2006 - Hygrocybe in Kerala State, India. Persoonia 19(1), 101-151.

Maire R. 1933 - Fungi Catalaunici. Contributions à l'étude de la flore mycologique de la Catalogne. Treballs del Museu de Ciències Naturals de Barcelona 15, Sèrie Botanica 2, 3-120.

Mani S, Kumaresan V. 2009 - Occurrence of macrofungi on the Coromandel coast of Tamil Nadu, southern India. Journal of Threatened Taxa 1(1), 54-57. http://dx.doi.org/10.11609/JoTT.01773.54-7

Manjula B. 1983 - A revised list of the agaricoid and boletoid basidiomycetes from India and Nepal. Proceedings of Indian Academy of Sciences (Plant Science) 92, 81-213.

Mizuta Y. 2006 - Two new species and one new variety of Oudemansiella (Agaricales) from Japan. Mycoscience 47, 380-384. http://dx.doi.org/10.1007/S10267-006-0312-X

Mohanan C. 2003 - Mycorrhizae in forest plantations: association, diversity and exploitation in planting improvement. KFRI Research Report No. 252. Kerala Forest Research Institute, Peechi, Kerala, India.

Mohanan C. 2011 - Macrofungi of Kerala. KFRI Handbook No. 27, Kerala Forest Research Institute, Peechi, Kerala, India.

Moncalvo JM, Vilgalys R, Redhead SA, Johnson JE, James TY, Aime MC, Hofstetter V, Verduin SJW, Larsson E, Baroni TJ, Thorn RG, Jacobsson S, Clémençon H, Miller Jr. OK. $2002-$ One hundred seventeen clades of euagarics. Molecular Phylogenetics and Evolution 23, 357400. http://dx.doi.org/10.1016/S1055-7903(02)00027-1

Monks AJ. 1989 - A preliminary survey of the Hygrophoraceae of Tasmania. B.Sc. Honours Thesis, The University of Tasmania.

Montagne JC. 1856 - Sylloge generum specierumque cryptogamarum. Paris 498 p.

Moser MM. 1955 - Studien zur Gattung Oudemansiella Speg., Schleim-und Sammetrüblinge. Zeitschrift für Mykologie 19, 4-11.

Mueller GM, Wu QX, Huang YQ, Guo SY, Aldana-Gomez R, Vilgalys R. 2001 - Assessing biogeographic relationships between North American and Chinese macrofungi. Journal of Biogeography 28, 271-281. http://dx.doi.org/10.1046/i.1365-2699.2001.00540.x

Myers N, Mittermeier RA, Mittermeier CG, da Fonseca ABG, Kent J. 2000 - Biodiversity hotspots for conservation priorities. Nature 403, 853-858. http://dx.doi.org/10.1038/35002501

Natarajan K, Manjula B. 1981 - South Indian Agaricales-XIV. Indian Journal of Botany 4, 50-59. 
Natarajan K, Narayanan K, Ravindran C, Kumaresan V. 2005a - Biodiversity of agarics from Nilgiri Biosphere Reserve, Western Ghats, India. Current Science 88 (12), 1890-1893.

Natarajan K, Purushothama B. 1986 - South Indian Agaricales - XXI. Kavaka 14(1,2), 47-60.

Natarajan K, Purushothama B. 1989 - Two new agarics from South India. Mycological Research 92(1), 111-113. http://dx.doi.org/10.1016/S0953-7562(89)80107-8

Natarajan K, Purushothama B. 1994 (1995) - Studies on Indian Agaricales-XXIII. Kavaka 22/23, 47-51.

Natarajan K, Raman N. 1981 - South Indian Agaricales-VII. Nova Hedwigia 34, 163-176.

Natarajan K, Raman N. 1983 - South Indian Agaricales - A preliminary study on some dark spores species. Bibliotheca Mycologica, Vol 89. J. Cramer, Vaduz, Germany.

Natarajan K, Senthilarasu G, Kumaresan V, Riviere T. 2005b - Diversity in ectomycorrhizal fungi of a dipterocarp forest in Western Ghats. Current Science 88, 1893-1895.

Natarajan K. 1975 - South Indian Agaricales-I. Kavaka 3, 63-66.

Natarajan K. 1977 - South Indian Agaricales-III. Kavaka 5, 33-39.

Pahlevanlo A, Janardhana GR. 2012 - Diversity of Termitomyces in Kodagu and Need for Conservation. Journal of Advanced Laboratory Research in Biology 3(2), 54-57.

Pascal JP, Pelissier R. 1996 - Structure and floristic composition of a tropical evergreen forest in south-west India. Journal of Tropical Ecology 12, 191-214. http://dx.doi.org/10.1017/S026646740000941X

Pascal JP. 1988 - Wet evergreen forests of the Western Ghats of India: Ecology, structure, floristic composition and succession, Institute Francais de Pondicherry, Pondicherry.

Patil MS, Thite AN. 1978 - Fungal flora of Amboli (Ratnagiri). Journal of Shivaji Univesity (Science) 18, 219-224.

Patil SD, Nair LN, Kapandis BP. 1979 - Studies on fleshy fungi of Western India. Journal of University of Poona, Science \& Technology 52, 349-354.

Patouillard, N.T. 1887 - Les Hyménomycètes d'Europe. Anatomie et Classification des Champignons Supérieurs (Matériaux pour l'Histoire des Champignons. i). Paul Klincksieck, Paris, 166 pp.

Pegler DN, Vanhaecke M. 1994 - Termitomyces of Southeast Asia. Kew Bulletin 49, 717-736. http://dx.doi.org/10.2307/4118066

Pegler DN, Young TWK. 1987 - Classification of Oudemansiella (Basidiomycota: Tricholomataceae), with special reference to spore structure. Transactions of the British Mycological Society 87, 583-602. http://dx.doi.org/10.1016/S0007-1536(86)80099-7

Pegler DN. 1976 - Pleurotus (Agaricales) in India, Nepal and Pakistan. Kew Bulletin 21, 501-510.

Pegler DN. 1977 - A preliminary agaric flora of East Africa. Kew Bulletin Additional Series VI. Kew, Royal Botanic Gardens, Kew 620 p.

Pegler DN. 1983 - Agaric flora of the Lesser Antilles. Kew Bulletin Additional Series IX. Royal Botanic Gardens, Kew 668 p.

Pegler DN. 1986 - Agaric flora of Sri Lanka. Kew Bulletin Additional Series XII. Royal Botanic Gardens, Kew 519 p.

Petersen RH, Baroni TJ. 2007 - Xerula hispida and Xerula setulosa (comb. nov.), two similar subtropical New World agarics. Mycotaxon 101, 113-136.

Petersen RH, Halling RE. 1993 - Mating systems in the Xerulaceae: Oudemansiella. Transactions of the Mycological Society of Japan 34, 409-422.

Petersen RH, Hughes KW. 2005 - Une nouvelle espèce de Xerula: Xerula limonispora. Bulletin trimestriel de la Société mycologique de France 120, 37-49.

Petersen RH, Hughes KW. 2010 - The Xerula/Oudemansiella complex (Agaricales). Nova Hedwigia Beiheft 137, 1-625.

Petersen RH, Methven AS. 1994 - Mating systems in the Xerulaceae: Xerula. Canadian Journal of Botany 72, 1151-1163. http://dx.doi.org/10.1139/b94-141

Petersen RH, Nagasawa E. 2006 - The genus Xerula in temperate East Asia. Reports of the Tottori Mycological Institute 43, 1-49.

Petersen RH. 2000 - Rhizomarasmius, gen. nov. (Xerulaceae, Agaricales). Mycotaxon 75, 333-342. 
Petersen RH. 2008a - Scanning electron microscope images of basidiospores of Xerula (Physalacriaceae, Agaricales). Mycoscience 49, 19-34. http://dx.doi.org/10.1007/S10267007-0387-Z

Petersen RH. 2008b - Species of Xerula from sub-Saharan Africa. Fungal Diversity 30, 121-147.

Petersen RH. 2008c - The genus Xerula (Agaricales; Fungi) in Australia and New Zealand. Nova Hedwigia 87, 1-67. http://dx.doi.org/10.1127/0029-5035/2008/0087-0001

Pradeep CK, Vrinda KB. 2007 - Some noteworthy agarics from Western Ghats of Kerala. Journal of Mycopathological Research (1), 1-14.

Pradhan P, Dutta AK, Roy A, Basu SK, Acharya K. 2012 - Inventory and spatial ecology of macrofungi in the Shorea robusta forest ecosystem of lateritic region of West Bengal. Biodiversity 13(2), 88-99. http://dx.doi.org/10.1080/14888386.2012.690560

Pradhan P, Dutta AK, Roy A, Basu SK, Acharya K. 2013 - Macrofungal diversity and habitat $\begin{array}{lllll}\text { specificity: a case } & \text { a } & \text { 147-161. }\end{array}$ http://dx.doi.org/10.1080/14888386.2013.805660

Purushothama KB, Natarajan K. 1989 - Studies on South Indian Agaricales XXII. Advances in Plant Sciences 2(2), 250-256.

Pushpa H, Purushothama KB. 2011 - Leucocoprinus Pat. (Agaricaceae, Agaricales, Basidiomycota) In Bengaluru, Karnataka State, India. World Applied Sciences Journal 14(3), 470-475.

Pushpa H, Purushothama KB. 2012 - Biodiversity of Mushrooms in and Around Bangalore (Karnataka), India. American-Eurasian Journal of Agricultural \& Environmental Science 12(6), 750-759.

Putzke J. 2002 - Agaricales (Fungos - Basidiomycota) Pleurotóides No Rio grande Do Sul. I Anthracophyllum, Aphyllotus, Campanella, Chaethocalathus E Cheimonophyllum. Cademo de Pesquisa Sér. Bio., Santa Cruz do Sul 14(1), 45-66.

Qin J, Hao YJ, Yang ZL. Li YC. 2014. - Paraxerula ellipsospora, a new Asian species of Physalacriaceae. Mycological Progress 13(3), 639-647. http://dx.doi.org/10.1007/s11557013-0946-v

Rai M, Sen S, Dutta BB, Acharya K. 2005 - Some additions to the Coprinaceae of Sikkim Himalaya. Journal of Mycopathological Research 43, 101-103.

Ramírez-Cruz V, Guzmán G, Villalobos-Arámbula AR, Rodríguez A, Matheny PB, Sánchez-García M, Guzmán-Dávalos L. 2013. Phylogenetic inference and trait evolution of the psychedelic mushroom genus Psilocybe sensu lato (Agaricales). Botany 91, 573-591. http://dx.doi.org/10.1139/cib-2013-0070

Rawla GS, Arya S, Sarwal BM. 1983 - Species of Termitomyces Heim. from Chandigarh, India. Bibliotheca Mycologica 91, 13.

Reddy MS, Singla S, Natarajan K, Senthilarasu G. 2005 - Pisolithus indicus, a new species of ectomycorrhizal fungus associated with Dipterocarps in India. Mycologia 97(4), 838-843. http://dx.doi.org/10.3852/mycologia.97.4.838

Redhead SA, Ginns J, Shoemaker RA. 1987- The Xerula (Collybia, Oudemansiella) radicata complex in Canada. Mycotaxon 30, 357-405.

Redhead SA, Ginns J. 1980 - Cyptotrama asprata (Agaricales) from North America and notes on the five other species of Cyptotrama Sect. Xerulina. Canadian Journal of Botany 58, 731-740. http://dx.doi.org/10.1139/b80-093

Redhead SA, Vilgalys R, Moncalvo JM, Johnson J, Hopple JS. 2001 - Coprinus Persoon and the disposition of Coprinus species sensu lato. Taxon 50, 203-241. http://dx.doi.org/10.2307/1224525

Reid DA \& Eicker A. 1998 - South African fungi 6. The genus Lactocollybia (Basidiomycota) in South Africa. Mycotaxon, 66, 153-163.

Rexer K-H, Kost G. 1989a - Zur Systematik der agaricoiden Hymenomyceten I. Zur Morphologie, Anatomie und Ontogenese der Fruchtkoerper von Megacollybia, Oudemansiella, Strobilurus. Zeitschrift für Mykologie 55, 207-240.

Rexer K-H, Kost G. 1989b - Zur Systematik der agaricoiden Hymenomyceten II. Verwandschaftliche Beziehungen von Megacollybia, Oudemansiella, Strobilurus zur anderen 
Basidiomyceten, nebst Studien zur Ultrastruktur ihrer Cystiden. Zeitschrift für Mykologie 55, 241-252.

Roy A, Samajpati N. 1978 - Agaricales of West Bengal-II. Indian Journal of Mushroom 4(2), 17-23. Saini, NS, Atri NS, Gupta AK. 1991 - Additional studies on North West Indian Agarics. In: Indian Mushrooms: Proceedings of the National Symposium on musrooms, pp 7-12, Kerala Agricultural University, Kerala.

Sankaran KV, Florence EJM. 1995 - Macrofungal flora and checklist of plant diseases of Malayattoor forests (Kerala). Advances in Forestry Research in India. Vol. 12 (ed SK Mukherjee) International Book Distributors, Dehra Dun, 147-168.

Sargunum SD, Johnsy G, Samuel A, Kaviyarasan V. 2012 - Mushrooms in the food culture of the Kaani tribe of Kanyakumari district. Indian Journal of Traditional Knowledge 11, 150-153.

Sathe AV, Daniel J. 1980 - Agaricales (Mushrooms) of Kerala State. In: Agaricales (Mushrooms) of South West India. MACS Monograph. No. 1, 75-108.

Sathe AV, Deshpande S. 1980 - Agaricales (Mushrooms) of Maharashtra State. In: Agaricales (Mushrooms) of South West India. MACS Monograph. No. 1, 9-42.

Sathe AV, Deshpande S. 1982 - Agaricales of Maharashtra. In: Advances in Mycology \& Plant Pathology: Proceeding[s] of the National Symposium Held at Calcutta on 22nd, 23rd September, 1979, eds. S.B. Chattopadhyay \& N. Samajpati, Oxford \& IBH Publishing Company 81-88.

Sathe AV, Kulkarni SM. 1980 - Agaricales (Mushrooms) of Karnataka State. In: Agaricales (Mushrooms) of South West India. MACS Monograph No. 1, 43-73.

Sathe AV, Rahalkar SR. 1975 - Agaricales from South West India - I. Biovigyanam 1(1), 75-78.

Sathe AV, Rahalkar SR. 1976 - Proceedings of Symposium on Survey and Cultivation of edible mushrooms in India, Reg. Research Laboratory, Srinagar 77-80.

Segedin BP. 1994 - Studies in the Agaricales of New Zealand: new records and new species of the genera Cheimonophyllum, Mniopetalum, and Anthracophyllum (Tricholomataceae, Collybieae). New Zealand Journal of Botany 32, 61-72. http://dx.doi.org/10.1080/0028825X.1994.10410407

Semwal KC, Stephenson SL, Bhatt VK, Bhatt RP. 2014 - Edible mushrooms of the North Western Himalaya, India: a study of indigenous knowledge, distribution and diversity. Mycosphere 5(3), 440-461.

Senthilarasu G, Kumaresan V, Singh SK. 2010a - A new species of Hygrocybe in section Firmae from Western Ghats, India. Mycotaxon 111, 301-307. http://dx.doi.org/10.5248/111.301

Senthilarasu G, Kumaresan V, Singh SK. 2010b - A new species of Entoloma from Western Ghats of India. Mycotaxon 114, 61-65. http://dx.doi.org/10.5248/114.61

Senthilarasu G, Kumaresan V, Singh SK. 2010c - Hygrocybe manadukaensis sp. nov. in section Firmae from Western Ghats, India. Mycotaxon 114, 343-349. http://dx.doi.org/10.5248/114.343

Senthilarasu G, Natarajan K. 2003 - Additions to the genus Entoloma from India. Kavaka 31, 153159.

Senthilarasu G. 2014 - Diversity of agarics (gilled mushrooms) of Maharashtra, India. Current Research in Environmental and Applied Mycology 4(1), 58-78.

Senthilarasu G. 2015 - The lentinoid fungi (Lentinus and Panus) from Western Ghats, India. IMA Fungus 6(1), 119-128. http://dx.doi.org/10.5598/imafungus.2015.06.01.06

Sharma AD, Jandaik CL, Munjal RL. 1977 - Some fleshy fungi from Himachal Pradesh. Indian Journal of Mushrooms 3, 12-15.

Singer R. 1962a - The Agaricales in Modern Taxonomy. 2nd ed. J. Cramer, Weinheim 1-915.

Singer R. 1962b - Diagnoses fungorm novorum Agaricalium II. Sydowia 15, 45-83

Singer R. 1964 - Oudemansiellinae, Macrocystidiinae, Pseudohiatulinae in South America. Darwiniana 13, 145-190

Singer R. 1986 - The Agaricales in Modern Taxonomy. (4th ed.) Sven Koeltz Scientific Books. 78 Koenigstein, Germany 981 p. 
Singh J, Mehrotra BS. 1974 - A survey of the gilled mushrooms in India. Beih. Nova Hedwigia 47, 511-529.

Spegazzini C. 1881 - Fungi argentini. Anales de la Sociedad Cientifica Argentina 12, 13-30.

Swapna S, Abrar S, Krishnappa M. 2008 - Diversity of Macrofungi in Semi-Evergreen and Moist Deciduous Forest of Shimoga District-Karnataka, India. Journal of Mycology and Plant Pathology 38(1), 21-26.

Tewari VP, Singh RN. 1973 - New records of Agaricales from India. Norw. J. Bot. 20, 21-25.

Varghese SP, Pradeep CK, Vrida KB. 2010 - Mushrooms of tribal importance in Wayanad area of Kerala. Journal of Mycopathological Research 48(2), 311-320.

Vellinga EC. 2002 - New combinations in Chlorophyllum. Mycotaxon 83, 415-417.

Vellinga EC. $2010-$ Book reviews and notices. Mycotaxon 114, 487-500. http://dx.doi.org/10.5248/114.487

Vrinda KB, Pradeep CK, Deepa S, Abraham TK. 2003 - Some leucocoprinoid fungi from the Western Ghats. Mushroom Research 12(1), 1-7.

Vrinda KB, Pradeep CK, Pradeep NS, Abraham TK. 1995 - New records of Hygrocybe from India. Journal of Economic and Taxonomic Botany. 19(3), 576-584.

Vrinda KB, Pradeep CK, Pratheep NS, Abraham TK. 1996 - Agaricales from Western Ghats - I. Journal of Mycopathological Research 34(2), 119-123.

Vrinda KB, Pradeep CK. 2011 - Toxic and hallucinogenic mushrooms of Kerala. Journal of Mycopathological Research 49(2), 231-246.

Wang L, Yang ZL, Zhang LF, Mueller GM. 2008 - Synopsis and systematic reconsideration of Xerula s. str. (Agaricales). Acta Botanica Yunnanica 30(6), 631-644.

Watling R, Gregory NM. 1980 - Larger fungi from Kashmir. Nova Hedwigia 32, 494-564.

Yang ZL, Zang M. 1993 - Classification of the genus Oudemansiella Speg. in southwest China. Acta Mycologica Sinica 12, 16-27.

Yang ZL, Zhang LF, Mueller GM, Kost GW, Rexer KH. 2009 - A new systematic arrangement of the genus Oudemansiella s. str. (Physalacriaceae, Agaricales). Mycosystema 28, 1-13.

Yang ZL. 2000 - Further notes on the genus Oudemansiella from southwestern China. Mycotaxon 74, 357-366.

Young AM, Mills AK. 2002 - The Hygrophoraceae of Tasmania. Muelleria 16, 3-28. 